\title{
PELAKSANAAN PAJAK PENGHASILAN ATAS BELANJA DANA BANTUAN OPERASIONAL PENYELENGGARAAN PENDIDIKAN ANAK USIA DINI DI WILAYAH KPP PRATAMA TEGAL
}

\author{
Mutia Safia Khalida ${ }^{1)}$; Benny Setiawan ${ }^{2)}$ \\ 1) msafiakhalida@gmail.com, Politeknik Keuangan Negara STAN \\ 2) benny.setiawan@pknstan.ac.id @gmail.com, Politeknik Keuangan Negara STAN
}

\begin{abstract}
This study aims to determine the differences in the imposition of Article 22 Income Tax collection obligations on the expenditure of Operational Assistance Funds (BOP) for public and private Early Childhood Education (PAUD) institutions, as well as explore the problems faced by the PAUD Treasurer in fulfilling tax obligations in the form of withholding and/or tax obligations. or collection and deposit and reporting of Income Tax (PPh) Articles 21, 22, and 23 on the expenditure of the Operational Assistance for the Implementation of Early Childhood Education (BOP PAUD) received, as well as knowing the obstacles faced in the implementation of their tax obligations. This research is a mixed research by combining quantitative and qualitative descriptive data by analyzing various literatures, regulations, theories, and related research. The results showed that only State PAUD had the obligation to collect Article 22 Income Tax, while private PAUD was only obliged to act as a cutter. This study also shows the results that the PAUD Treasurer has not fully carried out the obligations of withholding, depositing, and reporting taxes properly due to various obstacles faced such as the constraint of the location of the Tax Service Office (KPP) and the Tax Counseling and Consulting Service Office (KP2KP) which are quite far away, lack of tax socialization from KPP, limited Human Resources (HR) and facilities and infrastructure of PAUD institutions and lack of tax knowledge owned by PAUD Treasurer

Keyword: Tax Obligations, Treasurer, Operational Assistance Funds for Early Childhood Education
\end{abstract}

\begin{abstract}
Abstrak
Penelitian ini bertujuan untuk mengetahui perbedaan pengenaan kewajiban pemungutan PPh Pasal 22 atas belanja dana Bantuan Operasional Penyelenggaraan (BOP) bagi lembaga Pendidikan Anak Usia Dini (PAUD) negeri dan swasta, serta menggali permasalahan yang dihadapi Bendahara PAUD dalam pemenuhan kewajiban perpajakan berupa kewajiban pemotongan dan/atau pemungutan serta penyetoran dan pelaporan Pajak Penghasilan ( $\mathrm{PPh})$ Pasal 21, 22, dan 23 atas belanja dana Bantuan Operasional Penyelenggaraan Pendidikan Anak Usia Dini (BOP PAUD) yang diterima, serta mengetahui kendala yang dihadapi dalam pelaksanaan kewajiban perpajakannya. Penelitian ini merupakan penelitian campuran dengan menggabungkan data kuantitatif serta kualitatif deskriptif dengan melakukan analisis atas berbagai literatur, peraturan, teori, dan penelitian yang terkait. Hasil penelitian menunjukan bahwa hanya PAUD negeri yang memiliki kewajiban selaku pemungut PPh Pasal 22, sementara PAUD swasta hanya berkewajiban selaku pemotong. Dari penelitian ini juga menunjukan hasil bahwa Bendahara PAUD belum sepenuhnya melaksanakan kewajiban pemotongan, penyetoran, dan pelaporan pajaknya dengan baik karena adanya berbagai kendala yang dihadapi seperti kendala letak Kantor Pelayanan Pajak (KPP) serta Kantor Pelayanan Penyuluhan dan Konsultasi Pajak (KP2KP) yang cukup jauh, minimnya sosialisasi pajak dari KPP, keterbatasan Sumber Daya Manusia (SDM) serta sarana dan prasarana lembaga PAUD dan kurangnya pengetahuan perpajakan yang dimiliki Bendahara PAUD.
\end{abstract}

Kata Kunci: Kewajiban Perpajakan, Bendahara, BOP PAUD

\section{PENDAHULUAN}

Pembangunan nasional menurut Undang-Undang Nomor 17 Tahun 2007 tentang Rencana Pembangunan Jangka Panjang Nasional Tahun 2005-2025 adalah serangkaian usaha pembangunan yang dilaksanakan secara berkelanjutan oleh bangsa Indonesia untuk mencapai salah satu tujuan terpenting negara yakni mencerdaskan kehidupan bangsa sebagaimana tertuang dalam alinea keempat Undang-Undang Dasar 1945.

Pencantuman kata mencerdaskan kehidupan bangsa dalam butir tujuan negara, mengandung makna adanya komitmen yang tinggi dari pemerintah selaku penyelenggara negara dalam penyediaan dan penyelenggaraan pendidikan yang layak serta bermutu bagi 


\section{EDUCORETAX}

Volume 1 No. 2, Juni 2021

seluruh warga negara Indonesia, hal ini karena pendidikan memegang peran vital dalam membangun sumber daya manusia Indonesia.

Dalam pelaksanaannya, penyelenggaraan pendidikan yang bermutu tentu tidak terlepas dari adanya kebutuhan pendanaan lembaga pendidikan berkaitan dengan penyediaan sarana penunjang guna mendukung pelaksanaan kegiatan pembelajaran yang berkualitas. Hal ini karena pembiayaan merupakan elemen cukup penting dalam penyelenggaraan dan peningkatan mutu pendidikan suatu negara. Oleh karena itu, pemerintah dengan fungsi pajaknya yakni budgetair berupaya semaksimal mungkin menyediakan anggaran yang memadai agar mampu membiayai kebutuhan penyelenggaraan pendidikan yang berkualitas. Hal tersebut karena pajak merupakan sumber pendanaan yang paling memungkinkan untuk diperoleh tanpa harus bergantung terhadap sumber daya alam serta bantuan asing (Direktorat Jenderal Pajak, 2016).

Kontribusi pajak dalam pendanaan pendidikan Indonesia dapat terlihat dari postur Anggaran Pendapatan Belanja Negara (APBN) yang diterbitkan oleh Kementerian Keuangan (2019) melalui sumbangsih sebesar $82 \%$ dari total penerimaan negara. Anggaran pendidikan dialokasikan sebesar 22\% dari APBN atau senilai Rp492,5 triliun untuk ditransfer ke daerah dan dikelompokkan ke dalam Dana Transfer Khusus, yang salah satu penggunaannya berkaitan dengan Dana Alokasi Khusus (DAK) nonfisik untuk pendidikan dalam bentuk pemberian Bantuan Operasional Penyelenggaraan (BOP) di tingkat Pendidikan Anak Usia Dini (PAUD).

Namun demikian, hal kontradiktif yang terjadi saat ini adalah besarnya belanja pada APBN dan APBD tersebut belum diimbangi dari sisi pemotongan dan/atau pemungutan pajaknya (Harjowiryono, 2019). Hal ini terlihat dari data laporan kinerja Direktorat Jenderal Pajak tahun 2019 yang menunjukan adanya penurunan tingkat pertumbuhan realisasi penerimaan PPh Pasal 21, PPh Pasal 22, dan PPh Pasal 23 dari tahun sebelumnya sebagaimana ditunjukan dalam Tabel 1.

Tabel 1 Tingkat Pertumbuhan Penerimaan PPh Pasal 21, 22, 23

\begin{tabular}{ccc} 
Jenis & $\mathbf{2 0 1 9}$ & $\mathbf{2 0 1 8}$ \\
\hline PPh Pasal 21 & $4.39 \%$ & $14.56 \%$ \\
\hline PPh Pasal 22 & $6.16 \%$ & $11.35 \%$ \\
\hline PPh Pasal 23 & $6.69 \%$ & $16.86 \%$
\end{tabular}

Sumber : Diolah oleh penulis dari Laporan Kinerja DJP Tahun 2019

Berdasarkan Tabel I.1 terlihat bahwa pada tahun 2019 terjadi penurunan pertumbuhan penerimaan $\mathrm{PPh}$ Pasal 21, 22, dan 23 dibandingkan tahun sebelumnya, yakni keterlambatan pertumbuhan PPh Pasal 21 sebesar 10,17\%, PPh Pasal 22 sebesar 5,19\% dan PPh Pasal 23 sebesar $10,17 \%$. Hal tersebut menunjukan adanya indikasi ketidakpatuhan dalam pelaksanaan kewajiban perpajakan, sehingga diperlukan adanya peran serta Wajib Pajak lembaga PAUD dalam memenuhi kewajiban perpajakan yang telah ditentukan agar kepatuhan Wajib Pajak secara umum dapat meningkat.

Harapan akan adanya peningkatan kepatuhan perpajakan tersebut, tentu juga harus diimbangi dengan pengetahuan pajak yang mumpuni pada diri Wajib Pajak. Pengetahuan perpajakan tersebut dapat diperoleh dari dari petugas pajak, televisi, radio, majalah pajak, surat kabar, buku-buku pajak, internet maupun dari pelatihan pajak (Maulid, 2016). Namun demikian, berdasarkan studi literatur yang dilakukan penulis di internet sebagai salah satu sumber pengetahuan Wajib Pajak, penulis masih menemukan adanya perbedaan penafsiran ketentuan perpajakan berkaitan dengan pemenuhan kewajiban pembuatan laporan pertanggungjawaban (LPJ) oleh Bendahara PAUD atas dana BOP yang telah diterima.

Perbedaan ini berkenaan dengan penerapan kewajiban pemungutan $\mathrm{PPh}$ Pasal 22 antara PAUD negeri dan swasta, karena Peraturan Menteri Keuangan Nomor 34 Tahun 2017 tentang Pemungutan PPh Pasal 22 Sehubungan dengan Pembayaran Barang dan Kegiatan di Bidang 


\section{EDUCORETAX}

Volume 1 No. 2, Juni 2021

Impor atau Kegiatan Usaha di Bidang Lain sebagimana telah diubah dengan Peraturan Menteri Keuangan Nomor 110/PMK.010/2018 (PMK Nomor 34/PMK.010/2017) belum secara jelas mengatur mengenai hal tersebut.

Sebagai contoh dalam artikel yang dimuat oleh Badan Pendidikan dan Pelatihan Keuangan (BPPK) di situs webnya, dijelaskan bahwa bagi PAUD negeri dan swasta memiliki kewajiban pajak yang berbeda berkaitan dengan pemungutan PPh Pasal 22 atas penggunaan dana BOP yang diterimanya, yakni hanya PAUD negeri yang memiliki kewajiban melakukan pemungutan PPh Pasal 22, sementara bagi PAUD swasta hanya berkewajiban atas aspek pemotongan $\mathrm{PPh}$ saja (Aji, 2020). Penjelasan tersebut tentunya bertolak belakang dengan Petunjuk Penatausahaan DAK Nonfisik BOP PAUD yang diterbitkan oleh salah satu Dinas Pendidikan Kabupaten yakni Dinas Pendidikan Kabupaten Sleman, yang menyebutkan baik untuk satuan PAUD negeri maupun swasta keduanya dibebaskan dari pengenaan PPh Pasal 22 atas penggunaan dana BOP yang diterimanya (Dinas Pendidikan Kabupaten Sleman, 2020).

Adanya perbedaan penafsiran perpajakan atas belanja dana BOP bagi PAUD negeri dan swasta yang terjadi di lapangan tersebut merupakan sebuah gap berkaitan dengan upaya Direktorat Jenderal Pajak (DJP) dalam meningkatkan kepatuhan perpajakan. Hal ini didukung dengan temuan dari pihak Inspektorat mengenai kesalahan lembaga PAUD dalam hal penggunaan dana BOP, dokumen pertanggungjawaban, serta pembayaran pajak yang harus dilaksanakan dari dana BOP (150 Lembaga PAUD Pahami Kewajiban Pajak, n.d).

Berdasarkan hasil pemeriksaan BPK terhadap 30 entitas bendaharawan negara dengan sampel $11 \mathrm{Kementerian/Lembaga,} 9$ provinsi dan 10 pemerintah kabupaten/kota menunjukan adanya beberapa permasalahan dalam pemungutan pajak seperti kekeliruan pengenaan pajak yang mengakibatkan kurang potong sebesar Rp 368,70 miliar, permasalahan keterlambatan penyetoran pajak dengan nilai potensi kerugian negara dari ketidakpatuhan mencapai $\mathrm{Rp}$ 859,64 miliar, dan tidak tersampaikan atau terlambatnya penyerahan Surat Pemberitahuan (SPT) pajak dengan potensi sanksi mencapai Rp 3,1 miliar (Djumyati, 2011).

Adanya berbagai bentuk permasalahan perpajakan yang ditemukan tersebut juga tercermin dalam beberapa penelitan terdahulu yang telah dilakukan dalam lingkup lembaga pendidikan, seperti ketidaksesuaian antara pelaksanaan pemotongan dan/atau pemungutan $\mathrm{PPh}$ atas dana bantuan pendidikan berupa BOP/BOS dengan ketentuan pajak yang berlaku, sebagaimana penelitian yang dilakukan di SMK Negeri 2 Sragen (Khoiriyah, 2020). Pembayaran pajak yang dilaksanakan secara sekaligus setiap triwulan oleh Bendahara BOS di SD Negeri Jetis 02 Semarang (Salsabila, 2020), dan tidak terlaksananya pelaporan SPT Masa atas pemotongan dan/atau pemungutan $\mathrm{PPh}$ yang telah dilakukan sesuai penelitian yang diambil di SMP Negeri 10 Tegal (Muafa, 2020).

Oleh karena itu, dari berbagai gambaran yang ada, melalui penelitian ini, penulis tertarik untuk meninjau berbagai gap yang terjadi di lapangan berkaitan dengan pemenuhan kewajiban perpajakan lembaga PAUD atas belanja dana BOP yang diterima, dengan mengambil studi kasus lembaga PAUD yang terdaftar di wilayah Kantor Pelayanan Pajak (KPP) Pratama Tegal dikarenakan belum adanya penelitian serupa yang membahas mengenai hal ini.

Dalam penelitian ini, penulis ingin mengetahui bagaimana ketentuan perpajakan atas penggunaan dana BOP yang diterima oleh PAUD negeri dan swasta terkait kewajiban pemungutan $\mathrm{PPh}$ Pasal 22, dan meninjau pelaksanaan pemotongan dan/atau pemungutan Pajak Penghasilan (PPh) Pasal 21, 22, 23 atas penggunaan dana BOP yang dilaksanakan oleh Wajib Pajak PAUD yang terdaftar di KPP Pratama Tegal, apakah atas kewajiban tersebut telah sesuai dengan ketentuan pajak yang berlaku? serta meninjau kepatuhan pelaksanaan penyetoran dan 


\section{EDUCORETAX}

Volume 1 No. 2, Juni 2021

pelaporan SPT Masa Wajib Pajak PAUD terkait penggunaan dana BOP. Hal ini untuk mengetahui kendala Bendahara PAUD dalam pelaksanaan kewajiban perpajakannya.

Tujuan penelitian adalah mengetahui ketentuan perpajakan atas dana BOP yang diterima oleh Wajib Pajak Pendidikan Anak Usia Dini (PAUD) negeri dan swasta berkaitan dengan pemungutan PPh Pasal 22, meninjau pelaksanaan kewajiban pemotongan dan/atau pemungutan Pajak Penghasilan Pasal 21, 22, 23 atas penggunaan dana BOP yang diterima oleh Wajib Pajak Pendidikan Anak Usia Dini (PAUD), mengetahui tingkat kepatuhan perpajakan Wajib Pajak Pendidikan Anak Usia Dini (PAUD) terkait penggunaan dana BOP ditinjau dari penyetoran dan pelaporan pajaknya, dan mengetahui kendala yang dihadapi Wajib Pajak Pendidikan Anak Usia Dini (PAUD) dalam melaksanakan kewajiban perpajakan atas penggunaan dana BOP yang diterimanya.

\section{KAJIAN PUSTAKA \\ Keuangan Negara}

Undang-Undang Nomor 17 Tahun 2003 tentang Keuangan Negara mengatur keuangan negara sebagai "Semua hak dan kewajiban negara yang dapat dinilai dengan uang serta segala sesuatu baik berupa uang maupun barang yang dapat dijadikan milik negara sehubungan dengan pelaksanaan hak dan kewajiban". Berdasarkan definisi yang tercantum dalam Undang-Undang maka pengertian keuangan negara tersebut salah satunya meliputi hak negara untuk memungut pajak sebagaimana tercantum dalam Pasal 2. Karena berdasarkan teori kewajiban pajak mutlak, negara merupakan satu-satunya lembaga yang berwenang dalam memungut pajak dan memaksa rakyat untuk membayar pajak, yang hasilnya digunakan oleh negara untuk membiayai kegiatan pemerintahan (Widayati dkk, 2010).

\section{Aspek Ketentuan Perpajakan}

Direktorat Jenderal Pajak (2019) menyatakan bendahara wajib melakukan pemotongan dan/atau pemungutan pajak atas penggunaan dana BOP yang diterima oleh lembaga PAUD sesuai dengan transaksi yang dilakukannya. Secara teori, pemotongan dan pemungutan pajak merupakan dua istilah yang seringkali dianggap sama namun memiliki makna berbeda. Menurut Setiawan dan Fitriandi $(2017,2)$ dalam bukunya menyatakan bahwa istilah pemotongan pajak memiliki arti adanya pengurangan terhadap jumlah yang diterima oleh penerima penghasilan, dan biasanya ditujukan untuk perlakuan aspek Pajak Penghasilan Pasal 21, Pasal 23, Pasal 26, dan Pasal 4 ayat (2), sedangkan istilah pemungutan pajak memiliki makna menambah jumlah yang dibayarkan kepada penerima penghasilan dan biasa ditemukan dalam ketentuan PPh Pasal 22.

\section{Kepatuhan Pajak}

Menurut Badan Pusat Pengembangan dan Bahasa (2016), kepatuhan berasal dari kata dasar patuh yang memiliki makna suka menurut (perintah, dan sebagainya); taat (pada perintah, aturan, dan sebagainya); serta berdisiplin. Dari kata dasar patuh tersebut, menurut Gibson (1991, dikutip dalam Andriana, 2019) kepatuhan dapat didefinisikan sebagai motivasi seseorang maupun kelompok atau organisasi untuk berbuat atau tidak berbuat sesuai ketetapan aturan yang ada. Hal tersebut sejalan dengan definisi kepatuhan pajak menurut Lesmana dkk. (2017) yang menafsirkan kepatuhan pajak sebagai keadaan Wajib Pajak dalam melaksanakan hak dan kewajiban secara disiplin sesuai peraturan perpajakan yang berlaku. Dalam hal ini kepatuhan pajak tersebut meliputi ketepatan waktu pelaporan semua informasi yang diperlukan, kebenaran pengisian jumlah pajak terutang, serta ketepatan waktu dalam pembayaran pajak (Pangestu dan rusmana, 2012, dikutip dalam Lesmana dkk, 2017). 


\section{EDUCORETAX}

Volume 1 No. 2, Juni 2021

Oleh karena itu, mengacu dari beberapa definisi yang ada, dapat disimpulkan bahwa kepatuhan Wajib Pajak memiliki keterkaitan dengan perilaku seseorang (Andriana, 2019). Dalam hal ini termasuk sikap Bendahara PAUD saat menjalankan kewajiban perpajakan lembaga atas belanja dana BOP yang diterimanya, yang juga diartikan sebagai kedisiplinan Bendahara PAUD dalam melaksanakan kewajiban perpajakan yang meliputi kewajiban pemotongan, dan/atau pemungutan, penyetoran, serta pelaporan pajak sesuai ketentuan.

\section{Teori Perilaku Terencana (Planned Behaviour)}

Ajzen (1991, dikutip dalam Andriana, 2019) mendasarkan teori perilaku terencana dalam tiga jenis pertimbangan yakni (1) Behavioral beliefs (keyakinan perilaku) yang merupakan dasar bagi seseorang untuk melakukan suatu tindakan dengan pertimbangan bermanfaat/menguntungkan serta tidak bermanfaat/tidak menguntungkan. (2) Normatif beliefs (norma subjektif) sebagai kondisi serta tekanan sosial yang dirasakan oleh seseorang dalam melakukan atau tidak melakukan suatu tindakan. (3) Control beliefs (keyakinan kontrol) didasarkan pada pertimbangan kemudahan maupun kesulitan dalam melakukan sesuatu. Berdasarkan teori tersebut, diketahui adanya keterkaitan antara teori perilaku terencana dengan penelitian ini, yaitu perilaku kepatuhan pemenuhan kewajiban perpajakan dipengaruhi oleh niat Wajib Pajak itu sendiri, yang ditentukan dalam tiga faktor yakni keyakinan perilaku, norma subjektif dan keyakinan kontrol yang dimiliki oleh Wajib Pajak.

\section{Penelitian Terdahulu}

Berdasarkan studi literatur yang dilakukan penulis, belum ditemukan adanya penelitian serupa yang membahas tentang kewajiban pajak atas belanja dana Bantuan Operasional Penyelenggaraan (BOP) yang diterima oleh lembaga PAUD sesuai dengan topik penelitian. Salayev et al. (2020) membahas tentang mekanisme perpajakan bagi lembaga pendidikan secara umum yang meliputi institusi pendidikan prasekolah, lembaga pendidikan general, institusi pendidikan di luar sekolah, institusi pendidikan kejuruan khusus, perguruan tinggi, dan institusi pendidikan lainnya yang dikenakan pajak atas pendapatan, keuntungan, properti tanah, dan pemberian layanan yang disediakan, serta kewajiban bagi institusi dalam melaksanakan beberapa kewajiban terkait perpajakan seperti mendapat NPWP dari otoritas pajak, membayar pajak yang ditetapkan Undang-Undang disertai bunga dan sanksi keuangan, menyimpan catatan pendapatan dan pengeluaran objek pajak dengan cara yang ditentukan Undang-Undang, dan memberi perwakilan kepada orang-orang yang diwajibkan membuat pembukuan elektronik sesuai hukum Republik Azerbaijan, selain itu dalam penelitian ini juga membahas beberapa objek yang tidak dikenakan pajak serta beberapa masalah perpajakan di lembaga pendidikan terkait dengan definisi pendapatan dan pengeluaran yang dikecualikan dari dasar pengenaan pajak dan masalah perpajakan atas penghasilan yang diperoleh dari kegiatan komersial.

Khoiriyah (2020) dalam penelitiannya berfokus untuk mengetahui serta mengevaluasi pelaksanaan kewajiban pemotongan dan/atau pemungutan PPh Pasal 21, 22, dan 23. Dari penelitian tersebut menunjukan hasil masih ditemukannya kekeliruan dalam perhitungan $\mathrm{PPh}$ Pasal 21, tidak terpenuhinya kewajiban pemotongan dan/atau pemungutan $\mathrm{PPh}$ Pasal 21, 22, dan 23 terkait dengan beberapa transaksi belanja barang/jasa/modal yang berasal dari dana BOS, BOP, Revitalisasi, dan RPS, adanya kekeliruan penentuan objek dan Dasar Pengenaan Pajak (DPP) atas pemotongan dan/atau pemungutan $\mathrm{PPh}$, serta tidak terpenuhinya kewajiban pembuatan bukti potong atas $\mathrm{PPh}$ Pasal 21 dan 23. Hal ini dikarenakan masih kurangnya pemahaman bendahara berkaitan dengan kewajiban perpajakan yang harus dipenuhi, serta beban kerja bendahara yang dirasa terlalu tinggi.

Senada dengan penelitian yang dilakukan oleh Khoiriyah (2020). Salsabila (2020) dalam penelitiannya juga menunjukan hasil yang tidak jauh berbeda, dalam penelitian ini 


\section{EDUCORETAX}

Volume 1 No. 2, Juni 2021

beberapa kekeliruan yang terjadi meliputi ketidaksesuaian penerapan tarif dalam pemotongan PPh Pasal 21, tidak terlaksananya beberapa kewajiban pemotongan pajak terhadap objek yang seharusnya dipotong pajak, tidak terlaksananya pembuatan bukti potong, serta penyetoran pajak yang dilaksanakan secara sekaligus yakni setiap triwulan, dan tidak terpenuhinya kewajiban pelaporan SPT Masa untuk bulan Desember. Berbagai kekeliruan tersebut disebabkan adanya kendala teknis dan nonteknis yang mempengaruhi, yakni kendala teknis berkaitan penggunaan teknologi dengan bantuan komputer, serta kendala nonteknis berkaitan dengan kurangnya pengetahuan perpajakan yang dimiliki bendahara.

Mendukung penelitian Khoiriyah (2020), dan Salsabila (2020). Muafa (2020) dalam penelitiannya juga menunjukan hasil penelitian yang tidak jauh berbeda, yakni Bendahara SMP Negeri 10 Tegal juga belum mampu melaksanakan kewajibannya sesuai ketentuan perpajakan yang berlaku, beberapa kesalahan yang ditemukan meliputi salah hitung, tidak menerbitkan bukti potong atau bukti pungut atas pemotongan dan/atau pemungutan yang dilakukan, dan tidak terlaksananya pelaporan SPT Masa sesuai ketentuan yang berlaku.

Oleh karena itu, apabila dikomparasikan dengan penelitian terdahulu yang telah penulis sebutkan, maka perbedaan antara penelitian ini dengan penelitian sebelumnya terdapat pada objek penulisan yang merupakan lembaga Pendidikan Anak Usia Dini (PAUD) berupa tiga TK swasta di wilayah KPP Pratama Tegal sebagai sampel, dan perbedaan pengenaan pajak atas transaksi belanja lembaga PAUD yang berasal dari dana BOP, serta perbedaan tujuan penulisan yang tidak hanya membahas tentang pemotongan dan/atau pemungutan, penyetoran, dan pelaporan PPh Pasal 21, 22, 23 serta kendalanya semata, namun juga membahas perbedaan penafsiran aturan tentang kewajiban pengenaan PPh Pasal 22 bagi PAUD negeri dan swasta.

\section{METODE}

Dalam penelitian ini, penulis menggunakan desain penelitian campuran (mixed method) dengan mengombinasikan metode kuantitatif dan kualitatif. Metode ini diperlukan untuk menjawab rumusan masalah dan tujuan penelitian yang telah dipaparkan sebelumnya yang sulit untuk terjawab jika hanya menggunakan satu metode saja (Martono, 2015). Oleh karena itu, dengan menggunakan metode campuran maka data yang dihasilkan dapat lebih komprehensif guna meneliti masalah penelitian (Axin dan Pearce, 2006, dikutip dalam Martono, 2015).

Strategi penelitian yang penulis gunakan dalam penelitian ini ialah studi kasus, karena melalui studi kasus penulis dapat melakukan pendekatan guna melihat peristiwa di lapangan, serta memperoleh deskripsi yang mendalam dari sebuah fenomena untuk mewakili perspektif sumber informasi, sehingga dapat mencapai tujuan penelitian yang diharapkan dalam meninjau pelaksanaan pemotongan dan/atau pemungutan, penyetoran, serta pelaporan $\mathrm{PPh}$ atas belanja dana Bantuan Operasional Penyelenggaraan (BOP) Pendidikan Anak Usia Dini (PAUD) di wilayah KPP Pratama Tegal. Teknik pengumpulan data dalam penelitian ini antara lain wawancara dan dokumentasi. Penulis melakukan wawancara dengan narasumber dari seksi Peraturan dan Pemungutan PPh I Direktorat Peraturan Perpajakan II, Account Representative KPP Pratama Tegal, dan juga tiga sampel Bendahara TK di Kecamatan X Kabupaten Brebes yang menangani pajak atas penggunaan dana BOP, hal tersebut dilakukan untuk mengetahui ketentuan perpajakan bagi PAUD negeri dan swasta, pelaksanaan kewajiban perpajakan PAUD atas penggunaan dana BOP berkaitan dengan pemotongan dan/atau pemungutan serta penyetoran dan pelaporan PPh Pasal 21, 22, 23, dan juga kendala yang dihadapi Bendahara PAUD dalam pelaksanaan kewajiban perpajakannya. Pemilihan informan wawancara tersebut diambil dari narasumber yang berkompeten tentang permasalahan mengenai penelitian ini. 


\section{EDUCORETAX}

Volume 1 No. 2, Juni 2021

Wawancara dilaksanakan menggunakan media whatsapp sesuai kesepakatan dengan narasumber karena adanya pembatasan sosial akibat pandemi.

Penulis mengumpulkan data dan informasi melalui dokumen dan/atau literatur yang memuat teori, data, dan penelitian atau pembahasan yang relevan dengan topik penelitian. Jenis dokumen yang penulis gunakan berupa dokumen publik seperti peraturan perpajakan, dokumen personal yang berupa jurnal, serta dokumen organisasi yang berupa laporan pertanggungjawaban dana BOP tahun 2019 yang dibuat oleh Bendahara PAUD, serta data internal KPP Pratama Tegal yang meliputi data pembayaran dan pelaporan PPh Pasal 21, 22, 23 atas dana BOP yang diterima Wajib Pajak PAUD pada tahun 2019.

\section{HASIL DAN PEMBAHASAN}

\section{Ketentuan Pemungutan PPh Pasal 22 atas Belanja Dana BOP yang Diterima oleh PAUD}

Berdasarkan petunjuk teknis BOP PAUD yang diterbitkan oleh Kementerian Pendidikan melalui Permendikbud Nomor 4 Tahun 2019 sebagai landasan ketentuan penggunaan dana BOP bagi lembaga PAUD di tahun 2019, diketahui tidak disertai dengan adanya penjelasan mengenai jenis pajak apa saja yang menjadi kewajiban bagi lembaga PAUD atas dana BOP yang diterimanya. Apabila melihat dari ketentuan di dalam Permendikbud tersebut, petunjuk yang ada hanya mengatur jika kewajiban perpajakan atas belanja dana BOP ini mengikuti ketentuan pajak yang berlaku. Di sisi lain, apabila meninjau dari ketentuan perpajakan yang berlaku di Indonesia terutama PMK Nomor 34/PMK.010/2017 yang mengatur mengenai ketentuan pemungutan $\mathrm{PPh}$ Pasal 22 diketahui juga belum secara spesifik menjelaskan mengenai kewajiban pemungutan PPh Pasal 22 bagi PAUD negeri dan swasta. Hal tersebut menimbulkan adanya perbedaan penafsiran di lapangan mengenai ketentuan pemungutan PPh Pasal 22 atas belanja dana BOP bagi PAUD negeri dan swasta dalam berbagai literatur yang penulis temukan sebagaimana tercantum dalam Tabel 2.

Tabel 2 Perbedaan Penafsiran Pemungutan PPh Pasal 22 Bagi PAUD Negeri dan Swasta

\begin{tabular}{clllc} 
No & \multicolumn{1}{c}{ Sumber } & $\begin{array}{c}\text { Sekolah } \\
\text { Negeri }\end{array}$ & \multicolumn{1}{c}{$\begin{array}{c}\text { Sekolah } \\
\text { Swasta }\end{array}$} & \multicolumn{1}{c}{ Keterangan } \\
\hline & Keputusan Direktur Jenderal Pendidikan & & Tidak memiliki & Tidak \\
& kewajiban & menjelaskan \\
& Islam Nomor 7330 Tahun 2019 tentang & & memungut PPh & kewajiban \\
$1 \quad$ Petunjuk Teknis Pengelolaan Bantuan & - & Pasal 22 atas & pemungutan \\
& Operasional Pendidikan pada Raudlatul & & belanja barang & PPh Pasal 22 \\
& Athfal dan Bantuan Operasional Sekolah & & yang & bagi sekolah \\
& pada Madrasah Tahun Anggaran 2020 & dilakukan. & negeri \\
\hline
\end{tabular}

Petunjuk Pelaksanaan Penatausahaan

2 DAK Nonfisik BOP PAUD Tahun

Anggaran 2020 yang diterbitkan oleh

Dinas Pendidikan Kabupaten Sleman

Penetapan Bupati Lamandau Provinsi

3 Kalimantan Tengah Nomor 31 Tahun

2017 tentang Penggunaan Dana Bantuan

Operasional Pendidikan Anak Usia Dini

Peraturan Bupati Tanah Bumbu Provinsi

Kalimantan Selatan Nomor 42 Tahun

42018 tentang Petunjuk Teknis Penggunaan

Dana Bantuan Operasional Pendidikan

Untuk Pendidikan Anak Usia Dini, Taman
Kewajiban memungut dan menyetor PPh Pasal 22 sebesar $1.5 \%$ bagi lembaga PAUD untuk nilai pembelian lebih dari Rp2.000.000 (Dua juta Rupiah).
Tidak merinci, apakah meliputi PAUD negeri dan swasta 


\section{EDUCORETAX}

Volume 1 No. 2, Juni 2021

$\begin{array}{llc}\text { Kanak-kanak/Raudatul Atfal, dan } & & \begin{array}{c}\text { atau hanya } \\ \text { salah satu. }\end{array} \\ \text { Kelompok Bermain } & \text { Materi sosialisasi untuk bantuan sosial } & \text { Bukan } \\ \text { oleh Kementerian Pendidikan Nasional } & & \begin{array}{c}\text { pemungut, } \\ \text { hanya } \\ \text { Direktorat Jenderal Pendidikan Tinggi } \\ \text { berkewajiban } \\ \text { selaku }\end{array} \\ \begin{array}{l}\text { yang bekerjasama dengan Direktorat } \\ \text { Penyuluhan Pelayanan dan Humas }\end{array} & \begin{array}{c}\text { Pasal 22 } \\ \text { Direktorat Jenderal Pajak Kementerian }\end{array} & \text { pemotong } \\ \text { Keuangan }\end{array}$

Sumber : Diolah oleh Penulis.

Berkaitan dengan adanya perbedaan penafsiran ketentuan pemungutan PPh Pasal 22 bagi PAUD negeri dan swasta yang terjadi, tentu perlu dilakukan tinjauan lebih lanjut agar diperoleh kesamaan persepsi untuk kedepannya. Oleh karena itu, dalam pembahasan mengenai kewajiban pemungutan PPh Pasal 22 bagi PAUD negeri dan swasta ini, penulis mencoba meninjaunya dari dua sisi yakni dari sisi subjek dan objek PPh Pasal 22 sebagaimana diatur dalam PMK Nomor 34/PMK.010/2017. Hal ini untuk mengetahui apakah PAUD negeri dan swasta telah memenuhi ketentuan subjek dan objek pajak PPh Pasal 22 sesuai ketentuan yang berlaku sehingga dapat melaksanakan kewajibannya dalam memungut PPh Pasal 22 atas transaksi belanja operasional yang berasal dari dana BOP yang diterimanya.

1. Subjek Pajak PPh Pasal 22

Dari sisi subjeknya, pemungutan PPh Pasal 22 dapat dilakukan oleh sebelas pihak yang diberikan kewenangan secara jelas oleh pemerintah selaku pemungut Pajak Penghasilan Pasal 22 sebagaimana tercantum dalam PMK Nomor 34/PMK.010/2017 yang telah diubah dengan PMK Nomor 110/PMK.010/2018. Berdasarkan PMK tersebut, dapat terlihat jika tidak terdapat pencantuman Wajib Pajak PAUD baik negeri maupun swasta selaku pihak yang ditunjuk sebagai pemungut PPh Pasal 22.

Tidak tercantumnya PAUD Swasta ke dalam daftar pemungut PPh Pasal 22 tersebut, dikarenakan bagi PAUD swasta sendiri terdaftar dalam kategori badan usaha yang tidak ditunjuk pemerintah selaku pemungut $\mathrm{PPh}$ Pasal 22 selayaknya badan usaha tertentu, seperti badan usaha milik negara, badan usaha yang bergerak dalam bidang usaha industri semen, kertas, baja, otomotif, dan farmasi, atas penjualan hasil produksi kepada distributor dalam negeri, badan usaha yang melakukan pembelian komoditas tambang batubara, mineral logam, dan bukan logam, dari badan atau orang pribadi pemegang izin usaha pertambangan, atau badan usaha yang melakukan penjualan emas batangan di dalam negeri yang merupakan wajib pungut $\mathrm{PPh}$ Pasal 22. Oleh karena itu, PAUD swasta tidak perlu melakukan pemungutan PPh Pasal 22 saat melakukan belanja barang dengan menggunakan dana BOP PAUD. Hal tersebut sesuai dengan wawancara dengan Account Representative dari KPP Pratama Tegal.

"Iya betul mba, bagi PAUD swasta adalah badan usaha.....berbeda dengan PAUD negeri karena seperti bendahara instansi pemerintah.” (AR KPP Tegal)

Sementara itu, bagi PAUD negeri, meskipun juga tidak tercantum dalam daftar pemungut PPh Pasal 22 sebagaimana diatur di PMK Nomor 34/PMK.010/2017, namun dikarenakan lembaga/sekolah/pelatihan negeri memiliki kewajiban mendaftarkan NPWP ke KPP/KP2KP dengan nama bendahara instansi, maka sesuai dengan wawancara yang dilakukan penulis dengan pegawai Direktorat Peraturan Perpajakan II, narasumber berpendapat bagi PAUD negeri dapat dikategorikan sebagai pemungut sesuai ketentuan dalam PPh Pasal 22 karena tergolong dalam kategori Bendahara Pemerintah yang saat ini telah berubah ketentuan menjadi Instansi Pemerintah. 


\section{EDUCORETAX}

Volume 1 No. 2, Juni 2021

"Yang dimaksud instansi pemerintah adalah instansi pemerintah pusat, instansi pemerintah daerah, dan instansi pemerintah desa, yang melaksanakan kegiatan pemerintah serta memiliki kewenangan dan tanggung jawab pengguna anggaran, sehingga instansi pemerintah lembaga PAUD negeri termasuk sebagai instansi pemerintah yang wajib memungut PPh Pasal 22." (Direktorat PP II).

2. Objek Pajak PPh Pasal 22

Melihat dari sisi objek PPh Pasal 22, objek pajak pemungutan dilaksanakan atas penghasilan yang belum tentu akan jadi penghasilan bagi semua penerima uang, hal ini sesuai dengan ketentuan dalam PMK Nomor 34/PMK.010/2017 yang mengatur adanya beberapa pengecualian objek PPh Pasal 22, seperti pengecualian yang dikenakan atas dana Bantuan Operasional Sekolah yang bukan merupakan penghasilan bagi penerimanya sehingga dikecualikan dari objek pemungutan PPh Pasal 22.

Adanya pengecualian terhadap dana Bantuan Operasional Sekolah dalam objek pemungutan $\mathrm{PPh}$ Pasal 22 tersebut tentu menimbulkan pertanyaan berkaitan dengan penggunaan dana Bantuan Operasional Penyelenggaraan (BOP) yang diterima oleh PAUD baik negeri maupun swasta, apakah juga dikecualikan dari objek pemungutan $\mathrm{PPh}$ Pasal 22 seperti halnya dana BOS, karena dalam PMK Nomor 34/PMK.010/2017 sendiri tidak menyebutkan ketentuan penjelas yang mengatur mengenai adanya dana BOP dalam daftar pengecualian objek PPh Pasal 22 seperti halnya dana BOS.

Berdasarkan wawancara yang dilakukan oleh penulis dengan Account Representative KPP Pratama Tegal, tidak dikecualikannya BOP seperti halnya BOS dalam objek pemungutan PPh Pasal 22 karena adanya perbedaan filosofi peruntukan kedua dana bantuan pendidikan tersebut, yakni atas dana BOP sendiri ditujukan pada jenjang pendidikan yang bukan merupakan kategori wajib belajar yang diatur pemerintah yaitu pada jenjang lembaga pendidikan anak usia dini (PAUD), sementara BOS (Bantuan Operasional sekolah) diberikan untuk jenjang pendidikan yang merupakan bagian dari program wajib belajar pemerintah.

Oleh karena itu, berkaitan dengan kewajiban pajaknya, narasumber yang merupakan Account Representative KPP Pratama Tegal tersebut berpendapat bagi Bendahara PAUD negeri yang menangani belanja atas dana BOP ini dapat dipersamakan dengan kewajiban belanja bendahara pemerintah pada umumnya, dengan tetap melihat ketentuan lain berkaitan dengan objek PPh Pasal 22 itu sendiri. Hal ini karena tidak semua belanja yang dilaksanakan oleh PAUD negeri merupakan objek PPh Pasal 22 dan dapat dilaksanakan pemungutan PPh Pasal 22 meskipun bagi PAUD negeri sendiri berstatus sebagai pemungut.

Berdasarkan ketentuannya, pengenaan kewajiban pemungutan PPh Pasal 22 bagi PAUD negeri harus tetap melihat apakah jenis transaksi yang dilakukan oleh Bendahara PAUD negeri sendiri tergolong dalam jenis transaksi pengadaan barang dan jasa yang dibebaskan dari pemungutan $\mathrm{PPh}$ Pasal 22 atau tidak, sebagaimana tercantum dalam PMK Nomor 34/PMK.010/2017 yang mengatur mengenai pengecualian terhadap belanja barang apa saja yang tidak dapat dilakukan pemungutan $\mathrm{PPh}$ pasal 22, beberapa pengecualian tersebut seperti: (a) pembelian barang dengan maksimal nominal Rp2.000.000 dengan tidak terpecah dalam beberapa faktur; (b) pembelian bahan bakar minyak, listrik, gas, pelumas, air minum/PDAM dan benda-benda pos; (c) pembayaran untuk pembelian barang terkait dengan penggunaan dana Bantuan Operasional Sekolah (BOS).

Oleh karena itu, dalam hal ketentuan objek PPh Pasal 22 tersebut telah terpenuhi oleh PAUD Negeri dalam transaksi belanjanya, maka PAUD negeri selaku pihak yang ditunjuk sebagai pemungut PPh Pasal 22 memiliki kewajiban memungut PPh Pasal 22 atas transaksi belanja yang berasal dari dana BOP. Sementara itu, bagi PAUD swasta dikarenakan bukan 


\section{EDUCORETAX}

Volume 1 No. 2, Juni 2021

termasuk pemungut PPh Pasal 22 yang ditunjuk pemerintah maka PAUD swasta tidak dapat melakukan pemungutan PPh Pasal 22 atas belanja dana BOP yang diterimanya, meskipun memenuhi kriteria dalam ketentuan objek PPh Pasal 22 atas transaksi dan nominal pembayaran.

Hal tersebut sesuai edaran materi sosialisasi untuk bantuan sosial dari Kementerian Pendidikan Nasional Direktorat Jenderal Pendidikan Tinggi yang bekerjasama dengan Direktorat Penyuluhan Pelayanan dan Humas Direktorat Jenderal Pajak Kementerian Keuangan yang menjelaskan PAUD negeri merupakan pemungut PPh Pasal 22 dikarenakan terdaftar ke dalam NPWP Bendahara Pemerintah, sehingga memenuhi syarat untuk dikategorikan sebagai pemungut PPh Pasal 22 sebagaimana diatur dalam PMK Nomor 34/PMK.010/2017, sementara bagi PAUD Swasta hanya berkewajiban selaku pemotong semata.

Pelaksanaan Pemotongan dan/atau Pemungutan Pajak Penghasilan Pasal 21, 22, 23 atas Penggunaan Dana BOP oleh Wajib Pajak Pendidikan Anak Usia Dini (PAUD)

Berkaitan dengan tinjauan pemotongan dan/atau pemungutan pajak yang dilakukan oleh Bendahara PAUD atas belanja dana BOP yang diterima oleh TK Anggrek, Bugenvil, dan Calathea di tahun 2019, melalui pembahasan ini penulis terlebih dahulu melaksanakan identifikasi awal dari daftar uraian belanja atas dana BOP yang disusun oleh ketiga lembaga Taman Kanak-kanak yang terpilih, hal ini untuk mengetahui apakah atas belanja dana BOP yang diterima lembaga PAUD tersebut termasuk dalam objek PPh Pasal 21/22/23 yang dapat dilakukan pemotongan dan/atau pemungutan oleh ketiga lembaga PAUD selaku sampel dalam penelitian ini. Hal tersebut diperlukan agar nantinya penulis dapat meninjau kesesuaian perhitungan pemotongan dan/atau pemungutan yang telah dilakukan Bendahara TK Anggrek, Bugenvil, dan Calathea, dengan perhitungan berdasarkan ketentuan perpajakan yang berlaku.

Dalam melakukan identifikasi objek pajak tersebut, guna efektivitas pelaksanaan tinjauan, penulis hanya mengambil beberapa sampel data transaksi atas belanja dengan nominal terbesar saja. Dari identifikasi data belanja dana BOP yang dilakukan terhadap ketiga sampel Taman Kanak-kanak tersebut, dapat terlihat jika pada umumnya atas transaksi yang terjadi merupakan jenis transaksi yang bersifat rutin dan berulang. Beberapa transaksi yang umum terjadi meliputi transaksi atas belanja pegawai berupa pemberian honor transportasi kepada guru berkaitan acara seminar/rapat yang berpotensi menjadi objek PPh Pasal 21, dan transaksi atas pembelian barang dan jasa yang meliputi pembelian barang dengan nominal diatas dua juta rupiah yang berpotensi menjadi objek PPh Pasal 22, pembayaran jasa katering serta pembayaran jasa percetakan baik ke lawan transaksi yang merupakan badan atau orang pribadi yang berpotensi menjadi objek PPh Pasal 21, 22 atau 23.

Pemotongan PPh Pasal 21

1) TK Anggrek

Berdasarkan sampel yang diteliti, diketahui Bendahara TK Anggrek telah melakukan pemotongan PPh Pasal 21 berkaitan dengan pemberian honor transportasi rapat bagi guru yang bertugas pada tahun 2019 dengan cara mengglobalkannya dalam satu masa pajak yakni masa Desember sebesar Rp43.350. Dari perhitungan yang dilakukan tersebut Bendahara TK Anggrek telah membebankan PPh Pasal 21 atas transaksi pemberian honor transportasi rapat bagi dua orang guru yang merupakan guru PNS golongan III atas nama TS dan guru non-PNS atas nama KN dengan menggunakan perhitungan sesuai ketentuan dalam PER-16/PJ/2016 dengan tarif 5\% karena keduanya telah memiliki NPWP. Perhitungan PPh Pasal 21 dilakukan Bendahara TK Anggrek atas penggunaan dana BOP disajikan sebagaimana berikut ini. 


\section{EDUCORETAX}

Volume 1 No. 2, Juni 2021

\begin{tabular}{|c|c|c|c|c|}
\hline Tanggal pembayaran & Guru & $\begin{array}{c}\text { Uraian } \\
\text { transportasi }(\mathbf{R p})\end{array}$ & $\begin{array}{l}\text { Jumlah } \\
\text { (Rp) }\end{array}$ & $\begin{array}{c}\text { PPh } 21(5 \%) \\
\text { (Rp) }\end{array}$ \\
\hline \multirow[t]{2}{*}{2 Juli 2019} & $\mathrm{KN}$ & 5 bulan $x 56.700$ & Rp283.500 & Rp14.175 \\
\hline & TS & 5 bulan $\times 56.700$ & Rp283.500 & Rp14.175 \\
\hline \multirow[t]{3}{*}{23 Desember 2019} & $\mathrm{KN}$ & 5 bulan $\times 30.000$ & Rp150.000 & Rp7.500 \\
\hline & TS & 5 bulan $\mathrm{x} 30.000$ & Rp150.000 & Rp7.500 \\
\hline & & Total & Rp867.000 & Rp43.350 \\
\hline
\end{tabular}

Berdasarkan tinjauan penulis, atas perhitungan $\mathrm{PPh}$ Pasal 21 terkait pemberian honor transportasi yang dilakukan bendahara tersebut sudah tepat dilaksanakan dengan menggunakan tarif 5\% dari DPP sesuai ketentuan PER-16/PJ/2016 dengan berpedoman pada tarif PPh Pasal 17 Ayat 1 Undang-Undang PPh untuk guru non-PNS dan Peraturan Pemerintah Nomor 80 Tahun 2010 untuk guru yang berstatus PNS golongan III. Namun demikian, berkaitan dengan transaksi pada tanggal 2 Juli 2019 dan 23 Desember 2019 tersebut, seharusnya dapat dilakukan pemotongan pajak secara terpisah oleh bendahara, dan tidak diglobalkan dalam satu masa pajak. Hal ini dikarenakan adanya perbedaan saat terutang yang diatur dalam ketentuan perpajakan dalam PER-16/PJ.2016 yang mengharuskan atas PPh Pasal 21 tersebut terutang bagi pemotong untuk setiap masa pajak yakni pada akhir bulan dilakukannya pembayaran atau pada akhir bulan terutangnya penghasilan yang bersangkutan, sehingga berkaitan dengan pembayaran honor transportasi pada tanggal 2 Juli 2019 akan terutang dan dilaksanakan pemotongan PPh Pasal 21 masa Juli sebesar Rp28.350, dan untuk pembayaran honor transportasi tanggal 23 Desember 2019 akan terutang dan dilaksanakan pemotongan PPh Pasal 21 masa Desember sebesar Rp15.000 sebagaimana ditunjukan dalam perhitungan berikut.

\begin{tabular}{|c|c|c|c|c|}
\hline Tanggal pembayaran & Nama guru & $\begin{array}{l}\text { Uraian Biaya } \\
\text { (Rp) }\end{array}$ & $\begin{array}{c}\text { Jumlah } \\
\text { (Rp) }\end{array}$ & $\begin{array}{c}\text { PPh } 21 \\
\text { (Rp) }\end{array}$ \\
\hline \multirow[t]{3}{*}{$2 / 7 / 2019$} & $\mathrm{KN}$ & 5 bulan $x 56.700$ & 283.500 & 14.175 \\
\hline & TS & 5 bulan $x 56.700$ & 283.500 & 14.175 \\
\hline & \multicolumn{3}{|c|}{ PPh 21 seharusnya dipotong masa Juli 2019 (5\%) } & 28.350 \\
\hline \multirow[t]{3}{*}{$23 / 12 / 2019$} & $\mathrm{KN}$ & 5 bulan $x 30.000$ & 150.000 & 7.500 \\
\hline & TS & 5 bulan $\mathrm{x} 30.000$ & 150.000 & 7.500 \\
\hline & \multicolumn{3}{|c|}{ PPh 21 seharusnya dipotong masa Desember $2019(5 \%)$} & 15.000 \\
\hline
\end{tabular}

\section{2) TK Bugenvil}

Dari hasil tinjauan yang dilakukan penulis, bentuk kekeliruan yang tidak jauh berbeda juga penulis temukan dalam pemotongan PPh Pasal 21 atas transaksi yang terjadi di TK Bugenvil yang berasal dari penggunaan dana BOP. Berdasarkan data yang penulis peroleh, diketahui Bendahara TK Bugenvil juga mengglobalkan perhitungan pajak untuk transaksi masa Juni dan Desember senilai Rp25.920 terkait pemberian honor transportasi rapat bagi empat orang guru yang merupakan guru non-PNS dalam satu masa pemotongan pajak yakni masa Desember seperti ditunjukan dalam perhitungan berikut.

\begin{tabular}{lllll}
\hline $\begin{array}{c}\text { Tanggal pembayaran } \\
\text { transportasi rapat }\end{array}$ & Nama guru & $\begin{array}{l}\text { Uraian biaya } \\
(\mathbf{R p})\end{array}$ & $\begin{array}{l}\text { Jumlah } \\
(\mathbf{R p})\end{array}$ & $\begin{array}{l}\text { PPh 21 (6\%) } \\
(\mathbf{R p})\end{array}$ \\
\hline 22 Juni 2019 & $\mathrm{~F}$ & 3bulan $\mathrm{x} 18.500$ & 55.500 & 3.330 \\
\cline { 2 - 5 } & $\mathrm{Hv}$ & 3bulan $\mathrm{x} 18.500$ & 55.500 & 3.330 \\
\hline $\mathrm{Et}$ & 3bulan $\mathrm{x} 18.500$ & 55.500 & 3.330 \\
\cline { 2 - 4 } & $\mathrm{Yy}$ & 3bulan $\mathrm{x} 18.500$ & 55.500 & 3.330 \\
\hline
\end{tabular}




\section{EDUCORETAX}

Volume 1 No. 2, Juni 2021

\begin{tabular}{|c|c|c|c|c|}
\hline \multirow[t]{4}{*}{18 Desember 2019} & $\mathrm{~F}$ & 3bulan x 17.500 & 52.500 & 3.150 \\
\hline & $\mathrm{Hv}$ & 3bulan x 17.500 & 52.500 & 3.150 \\
\hline & Et & 3bulan x 17.500 & 52.500 & 3.150 \\
\hline & Yy & 3bulan x 17.500 & 52.500 & 3.150 \\
\hline \multicolumn{3}{|c|}{ Total PPh Pasal 21 yang dipotong masa Desember } & 432.000 & 25.920 \\
\hline
\end{tabular}

Selain itu, dari perhitungan tersebut, penulis juga menemukan kekeliruan lain dalam pengenaan PPh Pasal 21 yang dilakukan oleh TK Bugenvil berkaitan dengan pengenaan tarif PPh Pasal 21 atas pemotongan honor transportasi kepada guru TK Bugenvil. Dalam perhitungan yang dilakukan, diketahui bendahara membebankan pengenaan PPh Pasal 21 dengan tarif sama rata atas pemotongan pajak yang dilakukannya, yakni senilai 6\% untuk Pajak Penghasilan atas honor transportasi yang diberikan baik terhadap guru yang memiliki NPWP maupun tidak memiliki NPWP, sehingga hal tersebut tentu tidak sesuai dengan ketentuan yang diatur dalam PER-16/PJ.2016, yang mengatur atas honor transportasi bagi guru yang telah memiliki NPWP seharusnya dapat dipotong dengan tarif pengenaan 5\%. Oleh karena itu, perhitungan PPh 21 Masa Juni menurut penulis berdasarkan ketentuan PER-16/PJ.2016 adalah senilai Rp11.655 dan Masa Desember senilai Rp11.025 sebagaimana ditunjukan dalam perhitungan berikut ini.

\begin{tabular}{|c|c|c|c|c|}
\hline $\begin{array}{l}\text { Tanggal pembayaran } \\
\text { uang transportasi rapat }\end{array}$ & Nama guru & $\begin{array}{c}\text { Uraian biaya } \\
\text { transportasi } \\
(\mathrm{Rp})\end{array}$ & $\begin{array}{c}\text { Jumlah } \\
\text { (Rp) }\end{array}$ & $\begin{array}{c}\text { PPh 21 } \\
\text { (Rp) }\end{array}$ \\
\hline \multirow[t]{4}{*}{22 Juni 2019} & $\mathrm{~F}$ & 3bulan x 18.500 & 55.500 & 2.775 \\
\hline & $\mathrm{HC}$ & 3bulan x 18.500 & 55.500 & 2.775 \\
\hline & ES & 3bulan x 18.500 & 55.500 & 2.775 \\
\hline & SR & 3bulan x 18.500 & 55.500 & 3.330 \\
\hline \multicolumn{3}{|c|}{ PPh 21 yang dipotong masa Juni 2019} & 222.000 & 11.655 \\
\hline \multirow[t]{4}{*}{18 Desember 2019} & $\mathrm{~F}$ & 3bulan x 17.500 & 52.500 & 2.625 \\
\hline & $\mathrm{HC}$ & 3bulan x 17.500 & 52.500 & 2.625 \\
\hline & ES & 3bulan x 17.500 & 52.500 & 2.625 \\
\hline & SR & 3bulan x 17.500 & 52.500 & 3.150 \\
\hline \multicolumn{3}{|c|}{ PPh 21 yang dipotong masa Desember 2019} & 210.000 & 11.025 \\
\hline
\end{tabular}

Berkaitan dengan adanya kelebihan pemotongan PPh Pasal 21 yang dilakukan oleh Bendahara TK Bugenvil karena kekeliruan dalam menerapkan ketentuan tarif perpajakan, maka atas kelebihan pemotongan yang terjadi dapat diperhitungkan dengan $\mathrm{PPh}$ Pasal 21 yang terutang pada bulan berikutnya melalui Surat Pemberitahuan (SPT) Masa PPh 21, atau dapat dilakukan pemindahbukuan sesuai ketentuan yang berlaku.

3) TK Calathea

Selain TK Bugenvil, bentuk kekeliruan terkait pengenaan tarif $\mathrm{PPh}$ Pasal 21 juga penulis temukan dalam perhitungan pajak yang dilakukan oleh Bendahara TK Calathea. Dalam perhitungannya, diketahui Bendahara TK Calathea juga membebankan tarif pajak yang sama rata yakni $6 \%$ atas pembayaran honor transportasi untuk ketiga guru, baik yang telah memiliki NPWP maupun tidak memiliki NPWP, sehingga hal tersebut tentu tidak sesuai dengan ketentuan dalam PER-16/2016 yang mengatur adanya perbedaan pengenaan tarif PPh Pasal 21 bagi Wajib Pajak yang memiliki NPWP yakni senilai 5\%, dan Wajib Pajak yang belum memiliki NPWP yakni senilai 20\% lebih tinggi atau 6\% dari DPP.

Dalam hal ini, guna mempermudah tinjauan atas perhitungan pajak yang dilakukan, berikut penulis sandingkan perhitungan $\mathrm{PPh}$ Pasal 21 atas pembayaran honor transportasi berdasarkan perhitungan bendahara dan berdasarkan hasil perhitungan penulis sesuai ketentuan yang diatur dalam PER-16/2016. Dari hasil perhitungan tersebut, dapat terlihat adanya 


\section{EDUCORETAX}

Volume 1 No. 2, Juni 2021

kelebihan pemotongan pajak yang dilakukan oleh Bendahara TK Calathea senilai Rp7.260 (Rp65.340-Rp58.080) atas PPh 21 Masa Juni, serta Rp3.500 (Rp27.000-Rp24.000) di Masa Desember, sehingga apabila dalam suatu bulan terjadi kelebihan penyetoran pajak atas $\mathrm{PPh} 21$ yang terutang oleh pemotong PPh Pasal 21, maka atas kelebihan penyetoran tersebut dapat diperhitungkan dengan $\mathrm{PPh}$ Pasal 21 yang terutang pada bulan berikutnya melalui Surat Pemberitahuan (SPT) Masa PPh Pasal 21, atau dapat diselesaikan dengan mekanisme pemindahbukuan sesuai ketentuan pajak yang berlaku.

Selain itu, dari hasil tinjauan yang dilakukan penulis atas data transaksi LPJ BOP PAUD yang dibuat TK Calathea, penulis juga menemukan adanya kekeliruan dalam penentuan jenis pajak berkaitan dengan penggunaan dana BOP untuk pembayaran jasa katering kepada orang pribadi dalam rangka kegiatan parenting atau pertemuan wali murid yang seharusnya menjadi objek PPh Pasal 21 terkait penghasilan bukan pegawai.

Dalam perhitungannya, atas transaksi yang seharusnya menjadi objek PPh Pasal 21 tersebut, oleh Bendahara TK Calathea justru dimasukan ke dalam jenis pajak Pasal 23 dengan tarif 6\%. Hal ini karena bendahara beranggapan atas semua transaksi pembayaran katering merupakan objek PPh Pasal 23 tanpa melihat siapa lawan transaksi selaku penerima penghasilan tersebut, meskipun berdasarkan data yang diperoleh, bendahara juga masih keliru dalam menerapkan pengenaan tarif pajaknya.

Meninjau dari data transaksi pembayaran katering TK Calathea yang dilaksanakan lebih dari satu kali dalam satu tahun pajak yakni bulan Maret, Agustus, Oktober, dan November 2019 sebagaimana terlihat dalam Tabel 3, maka sesuai dengan Peraturan Dirjen Pajak Nomor PER16/PJ/2016, atas transaksi jasa katering tersebut dapat dikategorikan sebagai transaksi kepada bukan pegawai berkesinambungan yang merupakan objek PPh Pasal 21 dan dikenakan tarif PPh Pasal 17 Undang-Undang PPh dikalikan 50\% atas penghasilan bruto yang diterima.

Tabel 3 Data Transaksi Pembayaran Jasa Katering (Orang Pribadi)

\begin{tabular}{cllll}
\multirow{2}{*}{ Transaksi } & $\begin{array}{l}\text { Tanggal pada } \\
\text { nota }\end{array}$ & $\begin{array}{l}\text { Belanja BOP tahap 1 (6- } \\
\text { 2019) }\end{array}$ & $\begin{array}{l}\text { Tanggal } \\
\text { pada nota }\end{array}$ & $\begin{array}{l}\text { Belanja BOP tahap } \\
\mathbf{2}(\mathbf{1 2 - 2 0 1 9})\end{array}$ \\
\hline \multirow{3}{*}{$\begin{array}{l}\text { Jasa katering } \\
\text { hadiat ibu atin }\end{array}$} & Maret 2019 & Rp693.000 & Agus-19 & Rp950.000 \\
\cline { 2 - 5 } & - & - & Okt-19 & Rp350.000 \\
\cline { 2 - 5 } & - & - & Nov-19 & Rp950.000 \\
\cline { 2 - 5 } & - & - & Des-19 & Rp425.000
\end{tabular}

Diolah oleh Penulis dari LPJ BOP TK Calathea

Berkaitan transaksi pembayaran katering tersebut, melalui pembahasan ini, penulis mencoba menyajikan dua perhitungan pengenaan jasa katering baik apabila pemilik memiliki NPWP maupun tidak memiliki NPWP sebagaimana tersaji dalam Tabel 4, dan dalam hal pemilik katering tersebut memiliki NPWP, penulis tidak melakukan pengurangan Penghasilan Tidak Kena Pajak (PTKP) dalam perhitungan pajaknya, dengan asumsi pemilik jasa katering tersebut tidak hanya bekerja pada satu pemberi kerja atau TK Calathea semata, hal ini didukung dengan tidak adanya dokumen surat pernyataan hanya bekerja pada satu pemberi kerja yang diserahkan oleh pemberi jasa kepada Bendahara TK Calathea.

Tabel 4 Perhitungan PPh 21 atas Pembayaran Jasa Katering (Orang Pribadi)

\begin{tabular}{|c|c|c|c|c|c|c|}
\hline No & $\begin{array}{l}\text { Bulan } \\
(2019) \\
\end{array}$ & $\begin{array}{l}\text { Penghasilan } \\
\text { Bruto }\end{array}$ & $\operatorname{DPP}(50 \%)$ & $\begin{array}{l}\text { DPP } \\
\text { kumulatif }\end{array}$ & $\begin{array}{l}\text { Tarif } \quad 5 \% \\
\text { (NPWP) }\end{array}$ & $\begin{array}{l}\text { Tarif } \quad 6 \% \\
\text { (Non-NPWP) }\end{array}$ \\
\hline 1 & Maret & Rp693.000 & Rp346.500 & Rp346.500 & Rp17.325 & Rp20.790 \\
\hline 2 & Agustus & Rp950.000 & Rp475.000 & Rp821.500 & Rp23.750 & Rp28.500 \\
\hline 3 & Oktober & Rp350.000 & Rp175.000 & Rp996.500 & $\mathrm{Rp} 8.750$ & Rp10.500 \\
\hline 4 & November & Rp950.000 & Rp475.000 & Rp1.471.500 & Rp23.750 & Rp28.500 \\
\hline 5 & Desember & $\mathrm{Rp} 425.000$ & Rp212.500 & Rp1.684.000 & Rp10.625 & Rp12.750 \\
\hline
\end{tabular}




\section{EDUCORETAX}

Volume 1 No. 2, Juni 2021

PPh 21 terutang masa Desember 2019

Rp84.200

Rp101.040

Diolah oleh Penulis dari LPJ BOP TK Calathea

Berdasarkan perhitungan dalam Tabel 3, dikarenakan jumlah Dasar Pengenaan Pajak kumulatifnya belum melebihi tarif lapis pertama Pasal 17 Undang-Undang PPh yakni senilai Rp50.000.000, maka sesuai ketentuan yang berlaku, atas perhitungan PPh Pasal 21 tersebut tetap dilakukan pengenaan tarif 5\% bagi lawan transaksi yang memiliki NPWP, dan $6 \%$ bagi lawan transaksi yang tidak memiliki NPWP untuk dikalikan dengan Dasar Pengenaan Pajak (50\%), sehingga diperoleh hasil PPh Pasal 21 yang terutang Masa Desember atas jasa katering senilai Rp84.200 dalam hal pemilik katering memiliki NPWP dan Rp101.040 dalam hal pemilik katering ternyata tidak memiliki NPWP sesuai ketentuan yang diatur dalam PER-16/PJ/2016.

Namun demikian, dalam hal pemilik jasa katering tersebut ternyata memiliki NPWP dan memiliki Surat Keterangan PP 23 karena omset dalam satu tahun yang masih dibawah Rp4.800.000.000 serta mampu menunjukan fotokopi Surat Keterangan PP 23 tersebut kepada TK Calathea selaku pemberi kerja, maka atas transaksi tersebut harus dilakukan pengenaan pajak final dengan tarif $0.5 \%$ sesuai ketentuan PP 23 yang berlaku sehingga bukan lagi tergolong ke dalam objek pajak PPh Pasal 21, sebagaimana ditunjukan dalam perhitungan berikut.

\begin{tabular}{|ll|}
\hline Maret & $: 0.5 \%$ x Rp693.000 $=\mathrm{Rp} 3.465$ \\
Agustus & $: 0.5 \%$ xp950.000 $=\mathrm{Rp} 4.750$ \\
Oktober & $: 0.5 \%$ xp350.000 $=\mathrm{Rp} 1.750$ \\
November & $: 0.5 \%$ x R950.000 $=\mathrm{Rp} 4.750$ \\
Desember & $: 0.5 \%$ xp425.000 $=\mathrm{Rp} 2.125$ \\
\hline
\end{tabular}

\section{Pemungutan PPh Pasal 22}

Berdasarkan sampel transaksi yang diteliti penulis, dari transaksi pembelian yang dilakukan oleh TK Anggrek, Bugenvil, dan Calathea pada tahun 2019, dapat dilihat bahwa sebenarnya terdapat transaksi yang berpotensi menjadi objek PPh Pasal 22 seperti pembayaran atas bahan pembelajaran berupa buku gambar, kertas lipat, buku tulis, serta alat permainan edukasi yang berasal dari dana BOP yang diterima oleh lembaga PAUD. Hal ini karena nominal transaksi atas pembelian yang dilakukan tersebut telah melebihi Rp2.000.000 (tidak termasuk PPN) dan bukan merupakan pembayaran yang terpecah, serta atas pembelian yang dilakukan tidak termasuk dalam pengecualian objek PPh Pasal 22 sebagaimana yang tercantum dalam PMK Nomor 34/PMK.010/2017.

Namun demikian, dikarenakan ketiga TK tersebut bukan merupakan pemungut $\mathrm{PPh}$ Pasal 22 yang ditunjuk pemerintah sebagaimana diatur dalam PMK Nomor 34/PMK.010/2017 karena merupakan badan usaha PAUD swasta, maka atas belanja barang tersebut tidak perlu dilakukan pemungutan PPh Pasal 22, Oleh karena itu, dalam penelitian ini ketiga sampel PAUD swasta tersebut telah sesuai dalam memenuhi kewajiban perpajakannya dengan tidak melakukan pemungutan PPh Pasal 22 atas belanja dana BOP yang diterima.

\section{Pemotongan PPh Pasal 23}

Berdasarkan data transaksi belanja dana BOP TK Anggrek, Bugenvil, dan Calathea, diketahui terdapat beberapa transaksi yang berpotensi menjadi objek pajak dan dikenakan $\mathrm{PPh}$ Pasal 23, seperti transaksi pembayaran jasa katering, dan jasa percetakan banner yang dibayarkan kepada badan. Atas transaksi tersebut bendahara telah melakukan pemotongan $\mathrm{PPh}$ Pasal 23 sesuai yang tercantum dalam data dan fakta yang telah penulis jabarkan sebelumnya.

a) Pembayaran jasa katering 


\section{EDUCORETAX}

Volume 1 No. 2, Juni 2021

Berdasarkan tinjauan yang dilakukan penulis, secara keseluruhan, bendahara sudah benar memenuhi kewajiban perpajakan dengan mengenakan tarif $\mathrm{PPh}$ Pasal 23 atas pembayaran jasa katering yang dilaksanakan kepada badan, namun berdasarkan sampel yang penulis teliti, penulis masih menemukan adanya kekeliruan atas perhitungan pemotongan pajak yang dilakukan Bendahara TK Bugenvil, hal ini dikarenakan bendahara tetap mengenakan tarif PPh Pasal 23 sebesar 2\% meskipun pemberi jasa selaku lawan transaksi tersebut tidak menunjukan NPWP-nya. Padahal, apabila ditinjau dari aturannya, atas transaksi tersebut seharusnya dapat dilakukan pengenaan tarif $100 \%$ lebih tinggi yakni $4 \%$ dari penghasilan yang diterima sebagaimana ditunjukan dalam perhitungan berikut.

\begin{tabular}{lcc}
\hline $\begin{array}{l}\text { Pembayaran Makanan Tambahan Anak } \\
\text { dan Konsumsi }\end{array}$ & \\
TK Bugenvil Masa Juni & 4\% X Rp2.220.000 & Rp88.800 \\
\hline TK Bugenvil Masa Juni & 4\% xp1.110.000 & Rp44.400 \\
\hline \multicolumn{1}{c}{ Total PPh Pasal 23 atas jasa katering TK Bugenvil Masa Juni 2019 } & Rp133.200 \\
\hline TK Bugenvil Masa Desember & 4\% X Rp2.100.000 & Rp84.000 \\
\hline TK Bugenvil Masa Desember & 4\% xRp1.050.000 & Rp42.000 \\
\hline
\end{tabular}

Total PPh Pasal 23 atas jasa katering TK Bugenvil Masa Desember 2019

Rp126.000

Selain itu, berdasarkan sampel yang penulis teliti berkaitan dengan pemotongan $\mathrm{PPh}$ Pasal 23 yang dilakukan oleh Bendahara TK Calathea, penulis masih menemukan adanya kesalahan dalam pemotongan pajak dan kesalahan dalam menentukan jenis pajak atas transaksi pembelian makanan tambahan anak yang berupa pembelian makanan di warung, karena atas transaksi tersebut oleh Bendahara TK Calathea justru dilakukan pengenaan tarif PPh Pasal 23 meskipun tidak tergolong dalam jenis jasa katering yang diatur dalam ketentuan PPh Pasal 23.

Apabila meninjau dari ketentuan pajaknya, atas transaksi pembelian makanan tambahan anak yang berupa pembelian makanan di warung seharusnya dapat dikategorikan ke dalam objek pemungutan PPh Pasal 22 atas belanja barang yang menggunakan dana APBN/APBD apabila memenuhi ketentuan subjek dan objek pajak yang diatur dalam PPh Pasal 22. Namun, dikarenakan TK Calathea selaku pihak pembeli yang melaksanakan transaksi tersebut tidak memenuhi ketentuan subjek pajak selaku pemungut PPh Pasal 22 karena merupakan badan usaha pendidikan anak usia dini swasta, serta tidak memenuhi ketentuan objek pajak karena transaksinya tidak melebihi nominal Rp2.000.000, maka atas pembayaran makanan tambahan anak di warung yang dilakukan TK Calathea tersebut seharusnya bukan merupakan objek Pajak Penghasilan, dan tidak perlu dilakukan pemotongan dan/atau pemungutan Pajak Penghasilan baik Pasal 21, 22 maupun 23.

b) Pembayaran jasa percetakan

Terhadap pemotongan PPh Pasal 23 atas transaksi belanja jasa percetakan berupa pembayaran banner yang dilakukan bendahara, secara umum bendahara telah sesuai dalam melakukan pengklasifikasian jenis pajaknya, karena meskipun di dalam kuitansi tetera sebagai pembelian banner yang merupakan salah satu kategori belanja barang yang menggunakan APBN/APBD sehingga termasuk objek pemungutan PPh Pasal 22, namun dikarenakan dalam transaksi tersebut penentuan desain banner dilakukan oleh bendahara TK sendiri untuk kemudian dilakukan pemesanan oleh bendahara agar dapat dilaksanakan percetakan oleh jasa percetakan yang dipilih, maka berdasarkan wawancara yang dilakukan penulis dengan AR KPP Pratama Tegal, atas transaksi tersebut seharusnya bukan termasuk dalam kategori pembelian yang merupakan objek PPh Pasal 22, namun masuk dalam kategori jenis jasa percetakan sesuai yang tercantum dalam Pasal 1 Ayat 4 Huruf u PMK Nomor 141/PMK.03/2015, sehingga dapat 


\section{EDUCORETAX}

Volume 1 No. 2, Juni 2021

dikenakan PPh Pasal 23 dengan tarif 2\% bagi lawan transaksi yang memiliki NPWP dan 4\% bagi lawan transaksi non-NPWP.

Atas transaksi tersebut, dikarenakan secara nyata lawan transaksi selaku pihak pemberi jasa tidak memberitahukan NPWP kepada TK Anggrek, Bugenvil, maupun Calathea selaku penerima jasa, maka dalam perhitungan yang penulis lakukan dibawah ini, penulis menggunakan tarif PPh Pasal 23 senilai 4\%.

\begin{tabular}{lll}
\hline$-\quad$ TK Anggrek & & \\
\hline Pembayaran banner (pengadaan alat publikasi) masa Juli & $4 \%$ x Rp162.000 & $\mathrm{Rp} 6.480$ \\
\hline Pembayaran banner (pengadaan alat publikasi) masa Desember & $4 \%$ x Rp200.000 & $\mathrm{Rp} 8.000$ \\
\hline$\quad$ TK Bugenvil & & \\
\hline Pembayaran banner (pengadaan alat publikasi) masa Juli & $4 \%$ X Rp222.000 & $\mathrm{Rp} 8.880$ \\
\hline Pembayaran banner (pengadaan alat publikasi) masa Desember & $4 \%$ x Rp210.000 & $\mathrm{Rp} 8.400$ \\
\hline$\quad$ TK Calathea & & \\
\hline Pembayaran banner (pengadaan alat publikasi) masa Mei & $4 \%$ x Rp396.000 & $\mathrm{Rp} 15.840$ \\
\hline Pembayaran banner (pengadaan alat publikasi) masa Agustus & $4 \%$ x Rp140.000 & $\mathrm{Rp5.600}$ \\
\hline
\end{tabular}

Bukti Potong PPh Pasal 21 dan PPh Pasal 23

Berdasarkan wawancara yang dilakukan penulis terhadap Bendahara TK Anggrek, Bugenvil, dan Calathea diketahui atas pemotongan PPh Pasal 21 dan 23 yang telah dilakukan oleh ketiga bendahara tersebut ternyata tidak disertai dengan terlaksananya penerbitan bukti potong dengan menggunakan formulir 1721-VII untuk PPh Pasal 21 sesuai ketentuan yang berlaku dalam PER-14/PJ/2013 dan formulir F.1.1.33.06 untuk PPh Pasal 23 sesuai ketentuan dalam PER-4/PJ/2017, padahal apabila meninjau dari aturan tersebut, seharusnya bendahara atau dalam hal ini lembaga PAUD berupa Taman Kanak-kanak juga diwajibkan untuk membuat bukti pemotongan PPh Pasal 21 dan 23 atas pemotongan pajak yang telah dilakukan paling lama akhir bulan dilakukannya pembayaran honor.

Tidak terlaksananya kewajiban pembuatan bukti potong tersebut, karena dari bendahara sendiri tidak mengetahui adanya kewajiban mengenai hal ini serta tidak memahami tata caranya. Ketidaktahuan dan kurangnya pemahaman bendahara tersebut dimaklumi oleh Account representative KPP Pratama Tegal dikarenakan adanya faktor berupa keterbatasan sumber daya manusia di lembaga PAUD itu sendiri.

"Seharusnya demikian, membuat bukti potong atas setiap jenis transasksi yang dilakukan, dan itu harus sudah menggunakan aplikasi e-SPT. Hanya saja, belum semua PAUD memiliki sarana dan melek teknologi, apalagi e-SPT. Sehingga pada umumnya kami tekankan pada pemotongan dan pemungutannya serta penyetorannya dilakukan dulu." (AR KPP Tegal)

\section{Kepatuhan Penyetoran dan Pelaporan Pajak Wajib Pajak Pendidikan Anak Usia Dini (PAUD) Terkait Belanja Dana BOP}

Kewajiban perpajakan selanjutnya atas belanja dana BOP yang harus dilakukan lembaga PAUD setelah melakukan pemotongan dan/atau pemungutan pajak adalah melaksanakan penyetoran dan pelaporan SPT Masa atas PPh yang telah dipotong dan/atau dipungutnya, dengan indikator kepatuhan jatuh tempo waktu penyetoran dan pelaporan.

a) Penyetoran Pajak

Secara umum Bendahara TK selaku pihak yang bertanggung jawab dalam melaksanakan kewajiban pajak lembaga telah mengetahui adanya kewajiban pembayaran/penyetoran atas pajak yang telah dipotong dan/atau dipungutnya, hal ini berkaitan dengan adanya syarat dari Dinas Pendidikan Kabupaten yang mewajibkan lembaga PAUD untuk melampirkan bukti penyetoran pajak atas belanja dana BOP tahun 2019 dalam Laporan Pertanggungjawaban (LPJ) BOP yang harus dikumpulkan di akhir Januari tahun 2020. Namun dalam pelaksanaannya, pengetahuan akan kewajiban pembayaran pajak yang dimiliki oleh 


\section{EDUCORETAX}

Volume 1 No. 2, Juni 2021

bendahara tersebut belum dapat diimbangi dengan pemahaman ketentuan perpajakan yang mumpuni dari bendahara itu sendiri, hal ini dapat terlihat dari sampel data pembayaran SPT Masa PPh Pasal 21 dan Pasal 23 dalam Tabel 5.

\begin{tabular}{cllll}
\multicolumn{1}{c}{ TK } & \multicolumn{2}{c}{ Tabel 5 Data Pembayaran PPh Masa Lembaga PAUD } & \multicolumn{1}{c}{ Keterangan } \\
\hline \multirow{2}{*}{ TKh Anggrek } & 21 & Desember-19 & $3 / 1 / 2020$ & Tepat waktu \\
\cline { 2 - 5 } & 23 & Desember-19 & $2 / 1 / 2020$ & Tepat waktu \\
\hline \multirow{2}{*}{ TK Bugenvil } & 21 & Desember-19 & $30 / 12 / 2019$ & Tepat waktu \\
\cline { 2 - 5 } & 23 & Desember-19 & $30 / 12 / 2019$ & Tepat waktu \\
\hline \multirow{2}{*}{ TK Calathea } & 21 & Juni-19 & $14 / 01 / 2020$ & Terlambat \\
\cline { 2 - 5 } & 21 & Desember-19 & $14 / 01 / 2020$ & Terlambat \\
\cline { 2 - 5 } & 23 & Juni-19 & $14 / 01 / 2020$ & Terlambat
\end{tabular}

Sumber : Diolah oleh penulis dari LPJ BOP TK

Berdasarkan Tabel 5 terlihat 2 dari 3 sampel lembaga PAUD dalam penelitian ini telah melakukan penyetoran PPh Pasal 21 dan 23 secara tepat waktu, yakni pembayaran dilaksanakan paling lama sepuluh hari setelah masa pajak berakhir sesuai yang diatur dalam Peraturan Menteri Keuangan nomor 242/PMK.03/2014 tentang tata cara pembayaran dan penyetoran pajak. Namun berdasarkan data tersebut, diketahui masih terdapat satu lembaga PAUD lainnya yang belum mampu melaksanakan ketepatan waktu penyetoran pajaknya dengan baik, karena bendahara tersebut terlebih dahulu melakukan pengumpulan atas pemotongan pajak yang telah dilaksanakan agar dapat disetorkan di satu waktu bersamaan dengan tenggat waktu pengumpulan LPJ atas penggunaan dana BOP yang disyaratkan oleh Dinas Pendidikan Kabupaten, sehingga hal tersebut berakibat pada terlampauinya saat jatuh tempo pembayaran $\mathrm{PPh}$ Pasal 21 dan 23 yang diatur dalam ketentuan perpajakan.

Bentuk kekeliruan lain yang penulis temukan adalah adanya kesalahan penentuan Kode Jenis Pajak (KJP) dan Kode Jenis Setoran (KJS) dalam pembuatan billing berkaitan dengan penyetoran pajak yang harus dilaksanakan lembaga PAUD sebagaimana ditunjukan dalam Tabel 6. Berdasarkan ketentuan perpajakan yang berlaku, atas transaksi yang dikenakan $\mathrm{PPh}$ Pasal 21 seharusnya menggunakan Kode Jenis Pajak 411121 dan Kode Jenis Setoran 100, serta untuk PPh Pasal 23 seharusnya menggunakan Kode Jenis Pajak 411124 dan Kode Jenis Setoran 104, sehingga atas kekeliruan dalam pembayaran pajak yang telah terjadi dapat dilakukan pengajuan permohonan pemindahbukuan ke KPP terdaftar.

Tabel 6 Kesalahan Kode Jenis Pajak (KJP) dan Kode Jenis Setoran (KJS)

\begin{tabular}{|c|c|c|c|}
\hline TK & Jenis PPh & KJP-KJS & Seharusnya \\
\hline \multirow{2}{*}{ TK Anggrek } & 21 & $411121-100$ & Tepat \\
\hline & 23 & $411124-100$ & 411124-104 \\
\hline \multirow{2}{*}{ TK Bugenvil } & 21 & $411121-100$ & Tepat \\
\hline & 23 & $411124-100$ & 411124-104 \\
\hline \multirow{2}{*}{ TK Calathea } & 21 & $411121-100$ & Tepat \\
\hline & 23 & $411121-100$ & 411124-104 \\
\hline
\end{tabular}

Sumber : Diolah oleh penulis dari LPJ BOP TK

b) Pelaporan SPT Masa

Selain melakukan pemotongan dan penyetoran pajak, sesuai dengan ketentuan perpajakan yang berlaku, atas belanja dana BOP yang diterima oleh lembaga PAUD swasta yakni TK Anggrek, TK Bugenvil, dan TK Calathea selaku sampel dalam penelitian ini juga diharuskan melaksanakan kewajiban pelaporan SPT Masa PPh Pasal 21 dan 23 paling lambat dua puluh hari setelah masa pajak berakhir dalam hal pada masa tersebut terdapat transaksi pemotongan dan/atau pemungutan PPh yang dilakukannya, kecuali untuk SPT PPh Pasal 21 


\section{EDUCORETAX}

Volume 1 No. 2, Juni 2021

Masa Desember yang tetap harus dilaporkan meskipun pada bulan tersebut tidak terdapat transaksi pemotongan $\mathrm{PPh}$ Pasal 21.

Namun dalam pelaksanannya, sesuai dengan data yang diperoleh dari KPP Pratama Tegal, penulis tidak menemukan adanya data pelaporan SPT Masa PPh Pasal 21 maupun 23 di tahun 2019 terhadap ketiga lembaga PAUD yang menjadi sampel dalam penelitian ini. Berdasarkan wawancara yang dilakukan penulis dengan sampel bendahara, diketahui hal tersebut terjadi karena kurangnya pengetahuan bendahara yang bertugas menangani perpajakan atas dana BOP di lembaga PAUD, karena bendahara beranggapan kewajiban perpajakan atas belanja dana BOP yang diterima lembaga PAUD tersebut berhenti sampai pada pembayaran pajak yang telah dipotongnya saja, dan bendahara menganggap ketika bukti pembayaran tersebut telah dilampirkan dalam LPJ BOP yang dilaporkan ke Dinas Pendidikan, maka kewajiban perpajakan mereka berkaitan dengan belanja dana BOP juga telah usai.

Dalam hal ini minimnya tingkat kepatuhan pelaporan SPT Masa TK Anggrek, Bugenvil, dan Calathea tersebut, dapat penulis ringkas dalam Tabel 7 berikut ini.

Tabel 7 Data Kepatuhan Pelaporan SPT Masa PPh Pasal 21 dan 23

\begin{tabular}{|c|c|c|c|c|c|c|}
\hline \multirow{2}{*}{ Masa } & \multicolumn{3}{|c|}{ TK Anggrek, TK Bugenvil } & \multicolumn{3}{|c|}{ TK Calathea } \\
\hline & Lapor & Tidak & Ket & Lapor & Tidak & Ket \\
\hline Januari & - & - & $X$ & - & - & $\mathrm{X}$ \\
\hline Februari & - & - & $\mathrm{X}$ & - & - & $\mathrm{X}$ \\
\hline Maret & - & - & $\mathrm{X}$ & - & - & $\mathrm{X}$ \\
\hline April & - & - & $\mathrm{X}$ & - & - & $\mathrm{X}$ \\
\hline Mei & - & - & $\mathrm{X}$ & - & - & $\mathrm{X}$ \\
\hline Juni & - & - & $\mathrm{X}$ & - & $\mathrm{V}$ & 0 \\
\hline Juli & - & $\mathrm{V}$ & 0 & - & - & $\mathrm{X}$ \\
\hline Agustus & - & - & $\mathrm{X}$ & - & - & $\mathrm{X}$ \\
\hline September & - & - & $X$ & - & - & $X$ \\
\hline Oktober & - & - & $X$ & - & - & $X$ \\
\hline November & - & - & $X$ & - & - & $X$ \\
\hline Desember & - & $\mathrm{V}$ & 0 & - & $\mathrm{V}$ & 0 \\
\hline
\end{tabular}

Keterangan: $\mathrm{X}=$ tidak ada transaksi, $0=$ wajib lapor

Diolah oleh penulis dari LPJ BOP TK

Berdasarkan Tabel 7 tersebut, terlihat bahwa seharusnya pada tahun 2019 bagi lembaga TK Anggrek, dan Bugenvil diwajibkan untuk melaporkan SPT Masa PPh Pasal 21 serta 23 di masa Juli dan Desember, dan bagi TK Calathea diwajibkan melaporkan SPT Masa PPh Pasal 21 dan 23 untuk masa pajak Juni dan Desember sesuai ketentuan perpajakan yang berlaku, paling lambat dua puluh hari setelah masa pajak berakhir karena adanya transaksi pemotongan pajak yang telah dilakukan di masa tersebut. Namun dalam pelaksanaannya di lapangan, kewajiban pajak lembaga terkait pelaporan SPT Masa tersebut belum dapat dilaksanakan dengan baik oleh ketiga lembaga Taman Kanak-kanak selaku sampel dalam penelitian ini sesuai dengan ketentuan yang diatur dalam Peraturan Menteri Keuangan Nomor 9/PMK.03/2018 tentang perubahan atas Peraturan Menteri Keuangan Nomor 243/PMK.03/2014 tentang Surat Pemberitahuan (SPT).

\section{Kendala Lembaga Pendidikan Anak Usia Dini (PAUD) dalam Melaksanakan Kewajiban Perpajakan atas Penggunaan Dana BOP yang Diterimanya}

Berdasarkan hasil wawancara yang telah dilakukan penulis dengan Bendahara PAUD dan juga AR KPP Pratama Tegal, penulis menemukan beberapa kendala utama yang dialami lembaga PAUD berkaitan dengan pemenuhan kewajiban perpajakan atas belanja dana BOP yang diterima, beberapa kendala tersebut diantaranya: 


\section{EDUCORETAX}

Volume 1 No. 2, Juni 2021

a. Lokasi Kantor Pelayanan Pajak yang terbilang cukup jauh.

Meskipun sistem perpajakan di era sekarang ini telah dirancang melalui berbagai layanan online yang disediakan DJP guna memudahkan Wajib Pajak dalam melaksanakan kewajiban perpajakannya, namun berdasarkan wawancara yang dilakukan penulis, bagi bendahara lembaga PAUD sendiri merasa tetap memerlukan adanya konsultasi langsung secara tatap muka dengan account representative guna memastikan telah terpenuhinya kewajiban perpajakan lembaga PAUD atas dana BOP yang telah digunakan, hal ini karena belum semua bendahara memahami pelaksanaan kewajiban perpajakan secara online.

Namun demikian, dikarenakan lokasi KPP Pratama Tegal dan KP2KP Bumiayu yang dapat dikatakan cukup jauh karena memerlukan waktu tempuh kurang lebih satu setengah sampai dua jam perjalanan menjadikannya sebuah kendala bagi Bendahara PAUD di Kecamatan X untuk dapat datang ke KPP/KP2KP guna berkonsultasi langsung terkait kewajiban perpajakan yang harus dilaksanakannya. Hal ini dikarenakan adanya beban kerja yang juga harus dilaksanakan oleh Bendahara PAUD sebagai pengajar di sekolah setiap harinya, sehingga Bendahara PAUD biasanya hanya dapat berkonsultasi dengan account representative melalui layanan konsultasi via whatsapp dan menunggu sosialisasi yang diselenggarakan oleh Dinas Pendidikan serta KPP Pratama Tegal berkaitan dengan pengenaan aspek pajak atas belanja dana BOP yang menjadi kewajibannya.

b. Minimnya Sosialisasi Dari KPP

Dari hasil wawancara yang dilakukan penulis, diketahui sosialisasi yang dilaksanakan oleh KPP Pratama Tegal berkaitan dengan kewajiban perpajakan dana BOP sendiri dirasa masih kurang oleh Bendahara PAUD, karena sosialisasi terakhir dilaksanakan sekitar tahun 2018 yang lalu. Padahal dari bendahara sendiri menginginkan adanya sosialisasi perpajakan yang dapat dilaksanakan secara rutin setiap awal tahun untuk memudahkan mereka dalam melaksanakan kewajiban perpajakannya.

"Masih terasa kurang, karena tidak semua bendahara paham akan hal itu, inginnya setiap awal tahun dari pihak perpajakan itu mengulang kembali sosialisasi tersebut, karena sifat manusia memang sering lupa." (Bendahara TK Anggrek)

Ketika hal tersebut penulis coba konfirmasi kepada AR KPP Pratama Tegal, diperoleh penjelasan bahwa minimnya pemberian sosialisasi tersebut dikarenakan nominal pembayaran pajak lembaga PAUD yang rata-rata sangat kecil sehingga menjadi salah satu faktor belum terprioritaskannya pengawasan kepatuhan pajak pada lembaga PAUD. Karena sebagaimana diketahui, waktu yang dibutuhkan untuk sosialisasi berulang-ulang kepada lembaga PAUD dapat terbilang cukup menyita banyak waktu untuk pengawasan pajak utama atau strategis. Namun demikian, dari AR KPP Pratama Tegal sendiri senantiasa berusaha untuk tetap dapat menjadwalkan sosialisasi masal kepada lembaga PAUD di berbagai kesempatan.

c. Keterbatasan SDM dan Minimnya Sarana serta Prasarana Lembaga PAUD.

Berdasarkan penuturan AR KPP Pratama Tegal, belum optimalnya kepatuhan perpajakan lembaga PAUD dalam melaksanakan kewajibannya juga disebabkan karena minimnya jumlah sumber daya manusia serta sarana dan prasarana pada lembaga PAUD itu sendiri sebagaimana data dari Dinas Komunikasi Informatika dan Statistik Kabupaten Brebes yang tercantum dalam Tabel 8.

Tabel 8 Rasio Pendidikan Kabupaten Brebes Tahun 2019 (Negeri dan Swasta) Rasio

\begin{tabular}{lcccc}
\multirow{2}{*}{ Tingkat pendidikan } & \multicolumn{4}{c}{ Rasio } \\
\cline { 2 - 5 } & Guru/Sekolah & Guru/Kelas & Murid/Guru & Murid/Kelas \\
\hline TK & 3 & 1 & 18 & 19
\end{tabular}

Sumber: Dinas Komunikasi Informatika dan Statistik Kabupaten Brebes (2019) 


\section{EDUCORETAX}

Volume 1 No. 2, Juni 2021

Dari Tabel 8 menunjukan rasio jumlah guru TK di tiap sekolah yang hanya 3:1 atau bagi satu lembaga Taman Kanak-kanak hanya memiliki tiga sumber daya manusia yang bertugas selain sebagai guru juga melaksanakan tugas tambahan berkaitan pelaksanaan administrasi perpajakan lembaga atas belanja dana BOP yang diterimanya. Hal tersebut dilakukan, karena tidak adanya tenaga administrasi khusus yang menangani masalah perpajakan pada PAUD.

Selain itu, minimnya sarana dan prasarana seperti laptop dan pemahaman teknologi yang memadai guna pembuatan bukti potong maupun pelaporan pajak secara elektronik juga menjadi sebuah kendala berkenaan dengan pemenuhan kepatuhan perpajakan lembaga PAUD atas belanja dana BOP yang diterima.

d. Kurangnya pengetahuan perpajakan yang dimiliki Bendahara PAUD

Beberapa kewajiban perpajakan yang belum terlaksana oleh lembaga PAUD atas belanja dana BOP adalah pembuatan bukti potong dan pelaporan SPT Masa, hal ini dikarenakan kurangnya pengetahuan perpajakan bendahara terhadap kewajiban pajak lembaga PAUD. Karena hal yang dipahami oleh bendahara adalah kewajiban pajak atas dana BOP tersebut selesai sampai di penyetoran pajak saja.

Kondisi tersebut didukung dengan tidak pernah diterimanya Surat Tagihan Pajak (STP) dari KPP Pratama Tegal berkaitan dengan tidak terlaksananya kewajiban pelaporan SPT Masa atas pemotongan pajak yang telah dilaksanakan, selain itu dari Dinas Pendidikan sendiri juga hanya mewajibkan sebatas adanya lampiran bukti pembayaran pajak lembaga PAUD dalam pengumpulan laporan pertanggungjawaban (LPJ) atas dana BOP yang diterima oleh lembaga PAUD berkaitan dengan pemenuhan aspek pajaknya.

\section{PENUTUP}

\section{Simpulan}

Terdapat perbedaan ketentuan bagi PAUD negeri dan swasta berkaitan dengan kewajiban pemungutan PPh Pasal 22 atas belanja dana BOP, yakni bagi PAUD negeri merupakan pemungut PPh Pasal 22 selaku Bendahara Pemerintah sehingga wajib melakukan pemungutan PPh Pasal 22 atas belanja dana BOP yang diterima apabila telah memenuhi ketentuan batasan nominal pembelian barang yakni lebih dari Rp2.000.000 dan tidak terpecah ke dalam beberapa faktur, serta pembelian barang yang dilakukan tidak tergolong ke dalam jenis barang yang dibebaskan dari objek PPh Pasal 22, sementara bagi PAUD swasta bukanlah pemungut PPh Pasal 22 karena terdaftar selaku badan usaha yang tidak ditunjuk pemerintah sebagai pemungut PPh Pasal 22, sehingga tidak dapat melakukan pemungutan $\mathrm{PPh}$ Pasal 22 meskipun dalam transaksi yang terjadi memenuhi ketentuan objek PPh Pasal 22 terkait batasan dan jenis transaksi belanja dana BOP.

Beberapa kendala yang dihadapi lembaga PAUD terkait dengan terhambatnya pelaksanaan kewajiban perpajakan atas belanja dana BOP, diantaranya berupa:

a. Lokasi Kantor Pelayanan Pajak dan KP2KP yang aksesnya terbilang cukup jauh karena memerlukan waktu sekitar satu setengah sampai dua jam perjalanan, apabila Wajib Pajak hendak datang untuk berkonsultasi atau melaksanakan kewajiban perpajakannya secara langsung.

b. Minimnya sosialisasi yang dilakukan oleh KPP Pratama Tegal, karena berdasarkan wawancara yang penulis lakukan dengan bendahara, diketahui sosialisasi pajak dana BOP sendiri terakhir dilaksanakan sekitar tahun 2018 yang lalu dan belum dilaksanakan secara rutin setiap tahunnya, hal ini dikarenakan adanya faktor belum terprioritaskannya pengawasan kepatuhan pajak pada lembaga PAUD. 


\section{EDUCORETAX}

Volume 1 No. 2, Juni 2021

c. Minimnya sumber daya manusia yang bertugas, serta kurangnya sarana dan prasarana di lembaga PAUD. Hal tersebut terlihat dari rasio pendidikan di Kabupaten Brebes yang menunjukan di satu Taman Kanak-kanak hanya terdapat tiga sumber daya manusia yang bertugas selain sebagai guru juga harus melaksanakan kewajiban perpajakan lembaga PAUD atas belanja dana BOP yang diterimanya, ditambah lagi dengan minimnya sarana dan prasarana yang dimiliki lembaga PAUD seperti laptop guna membantu pelaksanaan administrasi perpajakan seperti pelaporan secara online, maupun pembuatan bukti potong elektronik.

d. Kurangnya pengetahuan perpajakan yang dimiliki Bendahara PAUD terkait kewajiban pajak atas penggunaan dana BOP yang telah dilaksanakan seperti kewajiban pembuatan bukti potong, dan pelaporan SPT Masa PPh Pasal 21 dan 23, dikarenakan bendahara beranggapan kewajiban perpajakan atas dana BOP ini selesai sampai pada penyetoran pajaknya saja.

Saran

Saran untuk penelitian selanjutnya disarankan untuk lebih menggali informasi kewajiban pajak lebih dalam terutama terhadap PAUD negeri dengan periode tahun penelitian terkini dikarenakan adanya keterbatasan penulis dalam melakukan penelitian yang dinilai kurang lengkap.

\section{DAFTAR PUSTAKA}

Aji, I. P. (2020, Januari 06). Wajib Pajak PAUD harus memungut PPh Pasal 22 dan PPN?. Kementerian Keuangan Badan Pendidikan dan Pelatihan Keuangan. Diakses tanggal 30 Oktober 2020, dari https://bppk.kemenkeu.go.id/content/artikel/balai-diklat-keuangan-balikpapan-wajibpajak-paud-harus-memungut-pph-pasal-22-dan-ppn-2020-01-06-aa03af2f/

Andriana, N. (2020). Kepatuhan Bendahara Desa dalam memenuhi kewajiban perpajakan dalam prespektif teori planned behavior. Jurnal Pajak Indonesia (Indonesian Tax Journal), $3(2)$

20-28. http://www.jurnal.stan.ac.id/index.php/JPI/article/view/737/429

Badan Pusat Pengembangan dan Pembinaan Bahasa. (2016). Patuh (Def. 1). Dalam Kamus Besar Bahasa Indonesia (KBBI) Online. diakses 9 Juli 2021 melalui https://kbbi.kemdikbud.go.id/entri/patuh.

Dinas Pendidikan Kabupaten Sleman. (2020). Penatausahaan DAK nonfisik BOP PAUD tahun anggaran 2020. Disdik.slemankab.go.id. https://disdik.slemankab.go.id/wpcontent/uploads/2020/07/JUKLAK-BOP-PAUD-2020.pdf

Direktorat Jenderal Pajak. (2013). Peraturan Direktur Jenderal Pajak Nomor PER-14/PJ/2013 tentang bentuk, isi, tata cara pengisian dan penyampaian Surat Pemberitahuan Masa Pajak Penghasilan Pasal 21 dan/atau Pasal 26 serta bentuk bukti pemotongan Pajak Penghasilan Pasal 21 dan/atau Pasal 26. Jakarta: Sekretariat Direktorat Jenderal Pajak.

Direktorat Jenderal Pajak. (2016). Materi terbuka kesadaran pajak untuk perguruan tinggi. Edukasi.Pajak.go.id.

https://edukasi.pajak.go.id/images/buku_pt/Materi_Terbuka/BukuMTKPPT2.pdf

Direktorat Jenderal Pajak. (2016). Peraturan Direktorat Jenderal Pajak Nomor 16 Tahun 2016 tentang pedoman teknis tata cara pemotongan, penyetoran, dan pelaporan Pajak Penghasilan Pasal 21 dan/atau Pajak Penghasilan Pasal 26 sehubungan dengan 


\section{EDUCORETAX}

Volume 1 No. 2, Juni 2021

pekerjaan, jasa, dan kegiatan orang pribadi. Jakarta: Sekretariat Direktorat Jenderal Pajak.

Direktorat Jenderal Pajak. (2017). Peraturan Direktur Jenderal Pajak Nomor PER-04/PJ/2017 tentang bentuk, isi, tata cara pengisian dan penyampaian Surat Pemberitahuan Masa Pajak Penghasilan Pasal 23 dan/atau Pasal 26 serta bentuk bukti pemotongan Pajak Penghasilan Pasal 23 dan/atau Pasal 26. Jakarta: Sekretariat Direktorat Jenderal Pajak.

Direktorat Jenderal Pajak. (2019, September 12). Kewajiban perpajakan bendahara dana $B O S / B O P$.

Pajak.go.id. https://www.pajak.go.id/sites/default/files/201909/SPL05\%20Bendahara\%20BOS.pd $\mathrm{f}$

Direktorat Jenderal Pajak. (2019). Laporan kinerja Direktorat Jenderal Pajak. Pajak.go.id. https://www.pajak.go.id/sites/default/files/202002/LAKIN\%20DJP\%202019.pdf

Djumyati, P. (23 November 2011). BPK: Kepatuhan pajak lembaga kementerian dan Pemda masih rendah. Nasional.Kontan.co.id. https://nasional.kontan.co.id/news/bpkkepatuhan-pajak-lembaga-kementerian-dan-pemda-masih-rendah

Harjowiryono, M. (2019). Analisis faktor-faktor yang memengaruhi kepatuhan bendahara pemerintah dalam penyetoran pajak. Indonesian Treasury Review: Jurnal Perbendaharaan, Keuangan Negara dan Kebijakan Publik, 4(3), 195-217. https://doi.org/10.33105/itrev.v4i3

Kementerian Agama. (2019). Keputusan Direktur Jenderal Pendidikan Islam Nomor 7330 Tahun 2019 tentang petunjuk teknis pengelolaan bantuan operasional pendidikan pada raudlatul athfal dan bantuan operasional sekolah pada madrasah tahun anggaran 2020. Jakarta: Sekretariat. Kementerian Agama.

Kementerian Keuangan. (2014). Peraturan Menteri Keuangan Republik Indonesia Nomor 242/PMK.03/2014 tentang tata cara pembayaran dan penyetoran pajak. Jakarta: Sekretariat Kementerian Keuangan.

Kementerian Keuangan. (2015). Peraturan Menteri Keuangan Republik Indonesia Nomor 141/PMK.03/2015 tentang jenis jasa lain sebagaimana dimaksud dalam Pasal 23 Ayat (1) Huruf c Angka 2 Undang-Undang Nomor 7 Tahun 1983 tentang Pajak Penghasilan sebagaimana telah beberapa kali diubah terakhir dengan Undang-Undang Nomor 36 Tahun 2008. Jakarta: Sekretariat Kementerian Keuangan.

Kementerian Keuangan. (2017). Peraturan Menteri Keuangan Nomor 34/PMK.010/2017 tentang pemungutan Pajak Penghasilan Pasal 22 sehubungan dengan pembayaran barang dan kegiatan di bidang impor atau kegiatan usaha di bidang lain. Jakarta: Sekretariat Kementerian Keuangan.

Kementerian Keuangan. (2018). Peraturan Menteri Keuangan Republik Indonesia Nomor 9/PMK.03/2018 tentang perubahan atas Peraturan Menteri Keuangan Nomor 243/PMK.03/2014 tentang Surat Pemberitahuan (SPT). Jakarta: Sekretariat Kementerian Keuangan.

Kementerian Keuangan. (2018). Peraturan Menteri Keuangan Republik Indonesia Nomor 99/PMK.03/2018 tentang pelaksanaan Peraturan Pemerintah Republik Indonesia Nomor 23 Tahun 2018 tentang Pajak Penghasilan atas penghasilan dari usaha yang diterima atau diperoleh Wajib Pajak yang memiliki peredaran bruto tertentu. Jakarta: Sekretariat Kementerian Keuangan.

Kementerian Keuangan. (2019). APBN 2019 adil, sehat, dan mandiri mendorong investasi dan saya saing Indonesia melalui pembangunan sumber daya manusia. Kemenkeu.go.id. https://www.kemenkeu.go.id/apbn2019 


\section{EDUCORETAX}

Volume 1 No. 2, Juni 2021

Kementerian Pendidikan dan Kebudayaan Republik Indonesia. (2019). Peraturan Menteri Pendidikan dan Kebudayaan Nomor 4 Tahun 2019 tentang petunjuk teknis penggunaan dana alokasi khusus nonfisik bantuan operasional penyelenggaraan pendidikan anak usia dini tahun 2019. Jakarta: Sekretariat Kementerian Pendidikan.

Kementerian Pendidikan Nasional, (n.d). Pajak untuk bantuan sosial. Dp2m.umm.ac.id. https://dp2m.umm.ac.id/files/file/Perpajakan\%20utk\%20Bansos-

Block\%20Grant\%20new\%20\%5bCompatibility\%20Mode\%5d.pdf

Khoiriyah, M. (2020). Tinjauan kepatuhan kewajiban pemotongan dan pemungutan Pajak Penghasilan Bendahara SMK Negeri 2 Sragen. (Karya Tulis Tugas Akhir, Politeknik Keuangan Negara STAN).

Lesmana, D., Panjaitan, D., \& Maimunah, M. (2017). Tax compliance ditinjau dari Theory of Planned Behavior (TPB): Studi empiris pada Wajib Pajak orang pribadi dan badan yang terdaftar pada KPP di Kota Palembang. Jurnal InFestasi, 13(2), 354-366. https://doi.org/10.21107/infestasi.v13i2.3514.g2585

Martono, N. (2015). Metode penelitian sosial: Konsep-Konsep kunci. PT Raja Grafindo Persada.

Maulid, M. T. (2016). Pengaruh pengetahuan perpajakan dan penegakan hukum pajak terhadap kepatuhan Wajib Pajak orang pribadi (studi kasus pada Kantor Pelayanan Pajak Cibeunying Bandung) (Doctoral dissertation, Universitas Widyatama).

Muafa, A.N. (2020). Tinjauan pelaksanaan kewajiban pemotongan dan pemungutan Pajak Penghasilan oleh Bendahara Pemerintah di SMP Negeri 10 Tegal. (Karya Tulis Tugas Akhir, Politeknik Keuangan Negara STAN).

Pemerintah Kabupaten Lamandau. (2017). Penetapan Bupati Lamandau Provinsi Kalimantan Tengah Nomor 31 Tahun 2017 tentang penggunaan dana bantuan operasional pendidikan anak usia dini. Lamandau: Sekretariat Daerah Provinsi Kalimantan Tengah.

Pemerintah Kabupaten Tanah Bumbu. (2018). Peraturan Bupati Tanah Bumbu Provinsi Kalimantan Selatan Nomor 42 tahun 2018 tentang petunjuk teknis penggunaan dana bantuan operasional pendidikan untuk pendidikan anak usia dini, taman kanakkanak/raudatul atfal, kelompok bermain. Tanah Bumbu: Sekretariat Daerah Provinsi Kalimantan Selatan.

Republik Indonesia. (2003). Undang-Undang Republik Indonesia Nomor 17 Tahun 2003 tentang keuangan negara. Jakarta: Sekretariat Negara.

Republik Indonesia. (2007). Undang-Undang Republik Indonesia Nomor 17 Tahun 2007 tentang rencana pembangunan jangka panjang nasional tahun 2005 -2025. Jakarta: Sekretariat Negara.

Republik Indonesia. (2008). Undang-Undang Republik Indonesia Nomor 36 Tahun 2008 tentang perubahan keempat atas Undang-Undang Republik Indonesia Nomor 7 Tahun 1983 tentang Pajak Penghasilan. Jakarta: Sekretariat Negara.

Republik Indonesia. (2009). Undang-Undang Republik Indonesia Nomor 16 Tahun 2009 tentang perubahan keempat atas Undang-Undang Nomor 6 Tahun 1983 tentang ketentuan umum dan tata cara perpajakan. Sekretariat Negara.

Republik Indonesia. (2010). Peraturan Pemerintah Republik Indonesia Nomor 80 Tahun 2010 tentang tarif pemotongan dan pengenaan Pajak Penghasilan Pasal 21 atas penghasilan yang menjadi beban Anggaran Pendapatan dan Belanja Negara atau Anggaran Pendapatan dan Belanja Daerah. Jakarta: Sekretariat Negara. 


\section{EDUCORETAX}

Volume 1 No. 2, Juni 2021

Salayev, R., Ramazanova, D., \& Allahverdiyeva, N. (2020). Problems of taxation of educational institutions at the modern stage of development of the economy of Azerbaijan. Economic and Social Development: Book of Proceedings, 4, 21-29. https://www.proquest.com/openview/3b80d60734170193d122e40a9c07c784/1?pqorigsite $=$ gscholar $\& \mathrm{cbl}=2033472$

Salsabila, Z. (2020). Tinjauan pemotongan dan pemungutan Pajak Penghasilan atas belanja dana BOS oleh bendahara BOS di wilayah KPP Pratama Salatiga (Studi Kasus SD Negeri Jetis 02 Kecamatan Bandungan Kabupaten Semarang). (Karya Tulis Tugas Akhir, Politeknik Keuangan Negara STAN).

Setiawan, Benny dan Fitriandi. (2017). Kupas tuntas PPh POTPUT: Penerapan aturan terbaru pemotongan dan pemungutan Pajak Penghasilan edisi 2. Jakarta: Salemba Empat.

Widayati, Wiwik., Harsasto. Astuti., Martini., dan Retno. (2010). Ekonomi pemerintahan. Universitas Terbuka.

http://repository.ut.ac.id/4253/1/IPEM4428-M1.pdf

150 Lembaga PAUD pahami kewajiban pajak. (n.d). Pajak.go.id.

https://pajak.go.id/id/berita/150-lembaga-paud-pahami-kewajiban-pajak 